\title{
HONOR STIRNA: MORDERSTWO, SZALEŃSTWO I NORMY SPOŁECZNE W OSIEMNASTOWIECZNYM LONDYNIE
}

\begin{abstract}
Abstrakt: Osiemnastowieczny Londyn stawał się miastem wielu mniejszości wyznaniowych i etnicznych. Artykuł na podstawie akt sądowych i relacji prasowych opisuje przypadek niemieckiego imigranta, który popełnił morderstwo, a potem targnął się na własne życie. Narracje poświęcone tej sprawie ukazują wyzwania akulturacji i mechanizmy społecznej alienacji w rynkowo zorientowanym wielkomiejskim środowisku.
\end{abstract}

Słowa kluczowe: zbrodnia, samobójstwo, szaleństwo, niedostosowanie, alienacja, akulturacja.
Abstract: London of the eighteenth century was becoming a city of confessional and ethnic diversity. Based on court and press reports, this article investigates a case of a German immigrant, who committed murder followed with a suicide. The narratives related to this case speak of aculturation challenges and mechanisms of social alienation, which were played out in a market-oriented urban environment.

Keywords: crime, suicide, madness, maladjustment, alienation, acculturation.

Stirn zastrzelił człowieka, a potem próbował popełnić samobójstwo. Morderstwo popełnił z premedytacją: kilka dni przedtem w sklepie rusznikarza nabył za znaczącą kwotę 18 szylingów dwa pistolety i kazał je nabić sprzedawcom. Strzelanie do ludzi - w tym przypadku z bliska, żeby zabić, przez szerokość stołu w oberży - nie było w osiemnastowiecznym Londynie codziennością. Podobnie było z morderstwami. Przestępczy półświatek stolicy Anglii charakteryzowały raczej napady, włamania, rozboje, kradzieże i bójki. Jeśli dochodziło w ich wyniku do czyjejś śmierci, sprawa nabierała wymiaru szczególnego ${ }^{1}$. Przypadek Stirna tym bardziej

1 Także na sali sądowej sprawom o mord i zabójstwo poświęcano więcej uwagi. Zob. akta rozprawy dziewięciu węglarzy oskarżonych w lipcu 1768 r. o to, że w czasie 
stał się głośny, że sprawca nie należał do bandyckiej i przestępczej subkultury, był przedstawicielem - choć, jak to pokażemy, nietypowym wielkomiejskiej inteligencji Londynu XVIII w.

Sprawę Stirna analizować będziemy z trzech perspektyw obecnych we współczesnych badaniach nad wczesnonowożytną przestępczością i ewolucją postaw wobec zbrodni i jej motywów. Po pierwsze, jako przypadek przestępstwa najbardziej społecznie widocznego - morderstwa nawiązując do dyskusji sięgającej tez sformułowanych jeszcze w $1897 \mathrm{r}$. przez Emila Durkheima o przyczynowym związku między wzrostem najcięższych przestępstw, a procesami urbanizacji i uprzemysłowienia, którą w kontekście angielskim zainicjował Lawrence Stone, a w europejskim starał się opisać Pieter Spierenburg². Po drugie, jako element debaty na temat ewolucji ocen samobójstwa, po trzecie wreszcie jako opis sprawy sądowej, gdzie rozważania, czy przestępca był umysłowo poczytalny w chwili popełnienia zbrodni, wpisywały się w refleksje prawników i orzecznictwo sądów na temat łagodzenia kar dla osób upośledzonych umysłowo. Podejmiemy też rozważania nad fabularną konstrukcją tej kryminalnej opowieści, łącząc ją z bogatą angielską tradycją literacką, w której relacje o zbrodniach, łotrzykowskie nowelki i współcześnie pisane powieści tworzyły złożony kulturowy amalgamat.

Pozostaje wreszcie pytanie ostatnie i najbardziej istotne: o miejsce migranta we wczesnonowożytnym mieście, o jego "niedopasowanie” kulturowe, które spychało go do kręgu londyńskiego „inteligenckiego proletariatu" i wykluczało z grona polite people, w czasach, kiedy owa "grzeczność", czyli ogłada, okazywała się miarą, wedle której układała się klasowa i towarzyska drabina społecznych odniesień.

Podstawą źródłową tego studium będą akta procesowe, sprawozdania prasowe, tzw. relacja kapelana z Newgate (Ordinary of Newgate Account) oraz wydana w kilka miesięcy po ogłoszeniu wyroku broszura napisana przez jednego ze świadków procesu, który proponował opinii publicznej swoją własną interpretację nie tyle wydarzeń, ile osobowości przestępcy ${ }^{3}$.

zbiorowej krwawej bijatyki z marynarzami w dokach Shadwell o prawo do rozładowywania statków z węglem zabili jednego z konkurentów, Old Bailey Session Papers (dalej: OBSP), ref. nr t17680706-57, http:// www.oldbaileyonline.org (dostęp 13 VII 2013).

2 L. Stone, Interpersonal Violence in English Society, 1300-1980, „Past \& Present” 101, 1983, s. 22-33; C. Emsley, Hard Men. Violence in England since 1750, London 2005; P. Spierenburg, A History of Murder. Personal Violence in Europe from the Middle Ages to the Present, Cambridge Mass. 2008.

3 Sprawę śledziły gazety codzienne: „London Chronicle” (11 IX 1760, 580), „Public Advertiser” (15 IX 1760, 8069), „Public Ledger” (27 IX 1760, 223), „Whitehall Evening Post" (11 IX 1760, 2261). Broszura pt. A circumstantial Account of Mr. Stirn etc., by 
Już w tym miejscu należy przytoczyć ostrzeżenie sformułowane przez Nicholasa Rogersa w odniesieniu do stosowanych procedur badawczych - i pokus - jakie pojawiają się w badaniu przypadków pochodzących ze źródeł sądowych, a tym bardziej ujęć seryjnych, zachęcających do statystycznych podsumowań. Rogers zwracał uwage, że wielokrotnie historyczna swada i swoisty „spin” - zarówno przekazu źródła, jak i analizującego je historyka - znacznie przeważają nad analitycznym ujęciem źródłowej substancji. Przestroga jest tym bardziej istotna, że w przypadku udostępniania i analizowania angielskiej serii materiałów sądowych tzw. Old Bailey Proceedings, projektu zainicjowanego w 2004 r., którego celem jest publikowanie online zapisu ponad 100000 spraw karnych, takie ostrzeżenia okazują się więcej niż rozsądne ${ }^{4}$.

Dodajmy już na wstępie, iż wymiar miejskiej topografii, zwykle istotny w analizowaniu zapisów przestępstw, nie ma tym razem aż tak dużego znaczenia. Zbrodnię popełniono w miejskiej oberży w północnym Londynie, pagórkowatej okolicy zwanej ogrodami Hattona (od nazwiska właściciela, biskupa diecezji Ely w XVI w.), przestrzeni otwartej (słynnej w XVI w. z pól truskawek), choć już w XVIII w. częściowo zabudowanej, leżącej na skraju „starego” miasta (londyńskiej City, tzn. w murach), blisko ruchliwego traktu Holborn, znanego z (mniej lub bardziej) godnych szacunku zajazdów i oberży, oraz jako trasa, którą wożono skazańców pod szubienicę przy Tyburn. Można odnieść wrażenie, że konflikt

Mr. Crawford ukazała się w październiku 1760 r. (wydawcą był znany londyński księgarz i promotor wydawania m.in. prasy kobiecej John Coote (1733-1808), cenę broszury ustalono na 1 szylinga). Została przedrukowana przez wiele periodyków, zob. „London Magazine" 29, 1760, s. 434 (omówienie sprawy), s. 478-480 (przedruk broszury), s. 490 (omówienie wyroku i dalsze wypadki), s. 560 (informacja o wydaniu broszury w dziale recenzji książkowych), „Universal Magazine” 27, 1760, s. 153-158 (tekst broszury oraz fragmenty tzw. relacji kapelana z Newgate), „Gentleman's Magazine” 30, 1760, s. 399-404 (reporterskie streszczenie procesu). Przebieg rozprawy cytuję za OBSP, www. oldbaileyonline.org (t17600910-19), pełny tekst relacji kapelana (Ordinary's Account), ref. nr OA17600915.

${ }^{4}$ N. Rogers, London's Marginal Histories, „Labour/Le Travail” 60, 2007, s. 217-234. Rogers wyraził taką opinię na marginesie omawiania książek napisanych przez Tima Hitchcocka (o londyńskiej biedocie) i Roberta B. Shoemakera (o rozruchach społecznych), koordynatorów tego projektu. Zob. T. Hitchcock, Down and Out in Eighteenth Century London, London-New York 2007; R. Shoemaker, The London Mob. Violence and Disorder in Eighteenth-Century England, London-New York 2004; T. Hitchcock, R. Shoemaker, Tales from the Hanging Court, London 2007. Podobną ocenę na temat wartości serii OBSP oraz źródeł sądowych jako gatunku wyrażali już J. Cockburn, Early Modern Assize Records as Historical Evidence, "Journal of the Society of Archivists” 5, 1975, s. 215-231; J.H. Langbein, The Criminal Trial before the Lawyers, „University of Chicago Law Review” 45, 1978, 2, s. $277 \mathrm{nn}$. 
dotyczył sąsiadów, ludzi, którzy mieszkali blisko siebie, w tej samej okolicy. Ofiara mieszkała przy Brook Street, niedaleko oberży Pewter Platter (Pod Cynową Misą), gdzie doszło do morderstwa, oberża zaś mieściła się obok szkoły, w której pracował morderca 5 .

Czas zatem opowiedzieć historię Francisa Davida Stirna, przedstawić fakty, zrekonstruować samo wydarzenie.

\section{Zabójstwo}

O mordercy wiemy stosunkowo niewiele. Miał 25 lat, był imigrantem, Niemcem z księstwa Kassel w Hesji, który przyjechał do Anglii w 1758 r., uciekając przed francuskimi wojskami. Pochodził z rodziny kalwińskich duchownych (ojciec, brat i on sam byli duchownymi), był świetnie wykształcony, m.in. w kolegium w Bremie. Przygotowywał się do podobnej innym członkom rodziny kariery, znał się na muzyce i autorach klasycznych. Jak pisano „pozyskał też znaczną zdolność hebrajskiego i był wielce sprawny w muzyce, zarówno śpiewie, jak instrumentalnej, w tańcu, szermierce i innych obyczajnych zdolnościach"6.

Pobyt w Anglii traktował zapewne jako wymuszony wojną epizod. Na pierwszy rzut oka Niemiec - kalwin - w monarchii rządzonej przez niemiecką (hanowerską i luterańską) dynastię, której pierwsi dwaj przedstawiciele nie znali angielskiego (Stirn także miał z tym pewne - ale mniejsze - kłopoty), nie powinien natrafiać na zbyt duże problemy adaptacyjne. W okresie wojny siedmioletniej w Londynie osiedliła się grupa niemieckich rzemieślników, w tym wysoko cenieni specjaliści zajmujący się budową instrumentów muzycznych - tacy jak Frederick Neubauer czy Johannes Zumpe - którzy osiągnęli wysoki status społeczny i znaczne dochody ${ }^{7}$. W Londynie Stirn znalazł osoby gotowe go wesprzeć, sądowe i prasowe relacje potwierdzają, że nie był w wielkim mieście sam, oraz

5 „Gentleman's Magazine” 30, 1760, s. 391, 403. Przy Brook Street mieszkał także poeta Thomas Chatterton, autor plagiatów, który popełnił tam samobójstwo 24 sierpnia 1770 r. Architekturę miasta całkowicie zmienił wiadukt (Holborn Viaduct) zbudowany w $1869 \mathrm{r}$.

${ }^{6}$ "he also acquired a very considerable skill in the Hebrew, and became a great proficient both in vocal and instrumental music, dancing, fencing and other polite accomplishments”, „Gentleman's Magazine” 30, 1760, s. 399.

7 Zob. np. R. Maunder, The Earliest English Square Piano?, „The Galpin Society Journal” 42, 1989, s. 77-84; M. Cole, Adam Beyer, Pianoforte Maker, „The Galpin Society Journal” 48, 1995, s. 94-119. Wielu z emigrantów przyjmowało brytyjskie obywatelstwo, zob. Letters of Denization and Acts Naturalization for Aliens in England and Ireland 1701-1800, red. W.A. Shaw, London 1923, s. 1-276, The Huguenot Society of London Publications 27. 
że znalazł możliwość pracy: „najpierw został zatrudniony jako pomocnik pana [Archibalda] Crawforda, kierownika szkoły [master of the accademy] na Cross Street w Hatton Garden [--] a potem, kiedy zostawił pana Crawforda, to pan Matthews zatrudnił go jako nauczyciela muzyki jego żony i córki, oraz żeby uczył go klasyków. W zamian miał otrzymać urządzony pokój i wyżywienie" ". Źródła ukazują narastanie osobistego konfliktu w ograniczonej przestrzeni domowych wspólnot i relatywnie zamkniętego środowiska, eskalację towarzyskiego sporu, która doprowadziła do tragedii.

Sprawa wydaje się z jednej strony pozornie banalna i niewarta szerszego potraktowania, z drugiej wpisuje się w rytm zjawisk społecznych o znacznie poważniejszych konsekwencjach. Nie ulega wątpliwości, że Stirn miał kłopoty $\mathrm{z}$ adaptowaniem się do narzuconych mu okolicznościami warunków. Mieszkając u Crawforda, swego pracodawcy, „mimo [--] dobroci i jej wyrazów zwykł sugerować - jak twierdził w sądzie chlebodawca - że ja, żona i służba próbowaliśmy go zamordować dodając mu trucizny do herbaty i innych napojów". Inni domownicy - żona i siostra gospodarza - zwracali mu uwagę, że w czasie pełni, wiosną i jesienią, Stirn był pobudzony („,agitated and stirred up”), a pewnego razu w napadzie furii porwał świecznik i zamierzył się nim na Crawforda. Gospodarz ostatecznie - na prośbę przestraszonej żony - wymówił mu w lipcu 1760 r. mieszkanie. Stirn przeniósł się do państwa Matthews. Był ich domowym nauczycielem, jednak już po dwóch miesiącach Richard Matthews wezwał do domu policjanta (constable) i dwóch przyjaciół, spakował dobytek Stirna i w środę 13 sierpnia 1760 r. po dziesiątej wieczorem, kiedy pedagog wrócił, poinformował go, że wymawia mu stancję. Mimo próby spokojnego załatwienia sprawy - Matthews zaproponował kieliszek wina - Stirn zachowywał się „nieracjonalnie”: kręcił się po mieszkaniu, uderzył kilka razy w klawisze szpinetu (dawny instrument muzyczny, odmiana klawesynu), zaproponował sprzedaż swoich (nielicznych) rzeczy, na pożegnanie chwycił go za rękę i zapowiedział zemstę ${ }^{9}$. Przez następne dwa dni - opieramy się i tym razem na zeznaniu Crawforda - stan nerwów Stirna ulegał pogorszeniu. W przekonaniu, że zawiązano przeciwko niemu spisek, a Matthews oskarżył go o kradzież

8 „The first employment he was engaged in was that of an assistant to Mr.Crawford master of the accademy in Cross street, Hatton Garden [--]. After Stirn left Mr. Crawford Mr. Matthews engaed him to teach his wife and daughter music and himself the classics for which he was to have a ready-furnished apartment and his board”, „Universal Magazine” 27, 1760, s. 153. Relacja w „Gentleman's Magazine” (30, 1760, s. 391) określa jego zajęcie w szkole Crawforda przy Cross Street jako „odźwierny” (usher).

9 OBSP, ref. nr OA17600915, s. 2 n., 12 (paginacja wydawcy). 
i uwiedzenie mu żony, coraz bardziej rozdrażniony - co uznano za znak, że chce popełnić samobójstwo, a nie morderstwo - Stirn kręcił się po okolicy, raz publicznie płakał i biadał, raz popadał w stan odrętwienia, aż w końcu wieczorem 15 sierpnia dotarł Pod Cynową Misę, gdzie spotkał Matthewsa biesiadującego ze znajomymi i po wygłoszeniu swoich pretensji i wymianie obelg, wyjął zza pazuchy pistolety i strzelił.

Zajmiemy się najpierw sprawą najprostszą - samym morderstwem. Przypadki przestępstw, w których ofiary poniosły świadomie zadaną śmierć, nie dominowały na mapie londyńskiej kryminalistyki w XVIII w. Relacje o nich w prasie - zwykle dość dokładne - świadczą raczej o szczególnej uwadze, jaką im poświęcano właśnie z powodu wyjątkowości. Patrick McCarty, były właściciel oberży King’s Head (na rogu Prince’s Street i Drury Lane), ścigany za długi (4 funty, zapewne znaczna dla niego kwota) zwabił windykatora do swego dawnego miejsca pracy i zabił jednym pchnięciem noża. Sprawie poświęcono odpowiednio więcej miejsca niż typowym dla stołecznej prasy statystykom wyliczającym skazanych za inne przestępstwa, które - choć także karane gardłem - nie dotyczyły morderstw ${ }^{10}$. Taką „medialną” praktykę potwierdzają liczne przykłady. Prasa szczegółowo relacjonowała przypadki Rachel Beacham, która zamordowała czteroletnią dziewczynkę z zemsty na jej matce, z którą się pokłóciła, okoliczności bójki ze śmiertelnym skutkiem wśród jeńców francuskich, sprawę zamordowania (i poćwiartowania zwłok) młodej dziewczyny przez dwie kobiety, proces kupca Suttona oskarżonego o seksualne wykorzystywanie i morderstwo oraz nauczyciela, który zamordował w nocy rodzinę i zażył śmiertelną dawkę opium. Dokładnie opisywano egzekucję matkobójcy, który zabił, „ponieważ biła go, gdy był małym chłopcem", oraz tajemnicze morderstwo wdowy Campion, właścicielki zajazdu w Wanstead ${ }^{11}$. Przypadki morderstw - przestępstw najbardziej bulwersujących i karanych stryczkiem - zajmowały w gazetach najwięcej miejsca, chociaż ich udział w londyńskiej strukturze

10 Uciekł z miejsca zbrodni, ale zatrzymał go żołnierz. Uznany winnym morderstwa z premedytacją, dwa tygodnie później został powieszony. „Zmarł jako katolik rzymski” napisano (był Irlandczykiem), a zakute w łańcuchy ciało zwyczajowo wystawiono na widok publiczny. Zob. „London Magazine” 29, 1760, s. 553. O Irlandczykach jako grupie szczególnie kryminogennej (w latach 1791-1805 14 proc. oskarżonych o morderstwo, mimo że stanowili 2-3 proc. ludności Londynu) zob. P. King, The Impact of Urbanization on Murder Rates and on the Geography of Homicide in England and Wales, 1780-1850, „The Historical Journal" 53, 2010, s. 695.

11 „London Magazine” 21, 1752, s. 42 (Beacham); ibidem, 23, 1754, s. 273 (bójka jeńców); ibidem, 31, 1762, s. 395, 421-425 (poćwiartowanie); „Universal Magazine” 28, 1761, s. 143-147 (Sutton); „Gentleman's Magazine” 35, 1765, s. 344 (nauczyciel); ibidem, 45, 1775, s. 403-404 (matkobójca, wdowa Campion). 
popełnionych przestępstw był niemal odwrotnie proporcjonalny do uwagi, jaką poświęcały im gazety.

Na podstawie relacjonowanych w prasie ośmiu posiedzeń londyńskiego sądu karnego (zw. Old Bailey) w 1758 r., w których wyliczano wydane wyroki, jesteśmy w stanie skonfrontować liczbę zasądzonych wyroków śmierci (nie tylko za popełnienie morderstwa) z innymi kategoriami kar. Karę główną otrzymało 15,6 proc. londyńskich podsądnych. Dane te moga stanowić przyczynek do statystyk, które analizował i prezentował Peter King, omawiając zjawisko „miejskich” przyczyn wzrostu liczby tej kategorii przestępstw ${ }^{12}$.

Tabela. Struktura informacji w „London Magazine” o wyrokach wydanych przez Królewski Trybunał Karny w 1758 r.

\begin{tabular}{|l|c|c|c|c|c|}
\hline $\begin{array}{c}\text { Data } \\
\text { informacji }\end{array}$ & $\begin{array}{c}\text { Wyrok } \\
\text { śmierci }\end{array}$ & Deportacja & $\begin{array}{c}\text { Publiczna } \\
\text { chłosta }\end{array}$ & $\begin{array}{c}\text { Napiętnowanie } \\
\text { żelazem }\end{array}$ & $\begin{array}{c}\text { Kara } \\
\text { więzienia }\end{array}$ \\
\hline 17 I 1758 & 8 & 11 & 3 & 4 & 2 \\
\hline 23 III 1758 & 1 & 27 & 4 & 1 & - \\
\hline 31 IV 1758 & 6 & 17 & 1 & 2 & - \\
\hline 11 V 1758 & - & 8 & - & - & - \\
\hline 29 VI 1758 & 2 & 21 & - & - & - \\
\hline 16 VII 1758 & 5 & 9 & 5 & 2 & - \\
\hline 16 X 1758 & 5 & 10 & - & 1 & 1 \\
\hline 18 XII 1758 & 2 & 23 & - & 5 & 3 \\
\hline Razem & 29 & 126 & 13 & 15 & - \\
\hline
\end{tabular}

Źródło: „London Magazine” 1758 (obliczenia własne).

W czasie wrześniowej sesji sądu w 1760 r., kiedy skazano Stirna, zapadło łącznie 26 wyroków, w tym dwa inne wyroki śmierci za popełnienie morderstwa. Wyrok oznaczał, że Stirn dołączył do grona 1242 osób, których przestępcze czyny wpisały ich - jak to sformułował Peter Linebaugh - do „tyburnografii”, dokładnie przez niego analizowanej listy

12 P. King, op. cit., s. 671-698. Panoramę świata londyńskiej przestępczości dla XVIXVIII w. omawiali m.in. J.L. McMullan, The Canting Crew. London's Criminal Underworld, 1550-1700, New Brunswick 1984; F. McLynn, Crime and Punishment in Eighteenth-Century England, London 1989; Policing and Prosecution in Britain 1750-1850, red. D. Hay, F. Snyder, Oxford 1989; J. Beattie, Crime and the Courts in England 1660-1800, Princeton 1986; idem, Policing and Punishment in London, 1660-1750. Urban Crime and the Limits of Terror, Oxford 2001. 
wisielców, którzy w okresie 1703-1772 zostali skazani na ostatnią podróż, na rozdroże Tyburn, gdzie wykonywano wyroki śmierci ${ }^{13}$.

Wiele światła na morderstwo popełnione przez Niemca rzucają „,społeczne" i psychologiczne uwarunkowania. Sprawca wydawał się niezdolny do aż tak drastycznego czynu. Przyjazny mu Crawford twierdził, że „Stirn zawsze cnoty miał w najwyższym poważaniu, a pogardzał rzeczami przyziemnymi i złem. Był młodzieńcem niezwykłej trzeźwości [--] drżał na myśl, że mógłby honor jakiejś damy narazić [--] był ponad swój wiek wykształcony [--] ale, umysł miał nieco wrażliwy". Panegiryk pobożnego protestanta kłócił się jednak z innym wizerunkiem, nakreślonym przez tego samego - życzliwego mu - obserwatora (piszącego w trzeciej osobie). Był to obraz człowieka przeżywającego głęboki stres: „Pan Crawford spotkał go w kawiarni Owensa przy Holborn, gdzie całkiem chłodno mówił na temat swojej kłótni z panem Matthews [--]. Poprosił o trochę kartofli i pintę portera, które natychmiast pożarł, chociaż wcześniej już jadł kolację, wypił też trzy miarki wina i pintę portera, dostatecznie dużo, aby jak na swoją niezwykłą trzeźwość stracić rozum"14. Co spowodowało, że wstrzemięźliwy i pobożny kalwin stał się tak nagle (bulimicznym?) pożeraczem kartofli i pijakiem?

Będziemy zmuszeni poddać się niełatwej próbie sprostania wymogom „historycznej psychologii”, czytać dostępne źródła jako zapis międzyludzkich konfliktów, emocjonalnych napięć - oraz ich skutków. Odtwarzając genezę konfliktu między Stirnem a ludźmi, którzy najpierw okazali mu

${ }^{13} \mathrm{Na}$ kary śmierci skazano marynarza Johna Dempseya oraz żołnierza Williama Odella (za zabójstwo żony, chociaż „do końca twierdził, że jest niewinny”). 20 osób skazano na 7 lat deportacji, dwie na publiczną chłostę, jedną na napiętnowanie żelazem. W poniedziałek 15 września Dempsey i Odell zostali powieszeni na Tyburn. Po egzekucji ciało pierwszego wisiało na szubienicy w łańcuchach - co było publicznym znakiem infamii, drugi trup został odesłany do gmachu cechu chirurgów. Zob. „London Magazine" 29, 1760, s. 490. Por. P. Linebaugh, The London Hanged. Crime and Civil Society in the Eighteenth Century, Cambridge 1992.

14 „Stirn always discovered an inviolable regard for virtue and the strongest detestation for everything base or vicious, he was the youth of uncommon temperance [--] that he abhorred the thought of attempting to dishonour any woman [--] that he was learned above his years but [--] his brain was somewhat touched”, „Universal Magazine” 27, 1760, s. 154 oraz „Mr. Crawford met him at Owen's coffee house in Holborn where he talked pretty cooly upon the subject of quarrel between him and Mr Matthews [--] he called for some potatoes and a pint of porter which he devoured ravenously, though he had supped before and drunk three gills of wine and a pint of porter, a sufficient quantity to deprive him of his senses considering his extraordinary temperance”, ibidem, s. 154. O londyńskich kawiarniach jako przestrzeni „mowy politycznej" oraz miejscu, gdzie relacje oparte o społeczny status ulegały zawieszeniu zob. J. Barrell, Coffee-House Politicians, „Journal of British Studies” 43, 2004, 2, s. 206-232. 
pomoc, a potem uznali go za zagrożenie, musimy zwracać uwagę na znaczeniowe niuanse słów, które wypowiadali świadkowie procesu, na zapisy stanów emocji i wrażliwości uczestników zajścia, które zaprowadziło niemieckiego nauczyciela przed londyński sąd. Crawford, autor umieszczonej w stołecznej prasie broszury, napisanej, aby naprawić błędne interpretacje, które pojawiły się w gazetach na temat zabójcy, wystąpił się w sądzie jako świadek obrony. Przez cztery godziny trwania procesu usiłowano ustalić fakty i odpowiedzieć na podstawowe pytania: czy to Stirn kupił pistolety i czy on - i w jakich okolicznościach - strzelał? Równolegle sąd usiłował ustalić, czy oskarżony był poczytalny. Motyw stanu umysłowego i emocjonalnego pojawił się wcześnie, świadkowie uznawali Niemca za osobę niezrównoważoną, ale swoimi opiniami wymusili podjęcie dyskusji, która została osadzona w trwałym w angielskiej kulturze i dyskursie prawnym toposie „morderczej melancholii”. Dwaj inni mordercy sądzeni w czasie wrześniowej sesji nie wzbudzili takich rozterek: pierwszy, marynarz, zabił swoją ofiarę ciosem kija z gwoździami, drugi - żołnierz udusił żonę, poćwiartował jej ciało i wrzucił do glinianki ${ }^{15}$. Przyczyny okrucieństwa tych czynów nie były - jak można sadzić - przedmiotem szczególnych deliberacji, obu prędko skazano i powędrowali na szubienicę.

\section{Szaleniec}

W sprawie Stirna wypowiedzi świadków wskazywały, że Niemiec był „niezrównoważony”, „,szalony”, że był „lunatykiem” i „wariatem”, co wprowadzało do języka rozprawy element naznaczony przez zbitkę pojęć głęboko osadzonych w osiemnastowiecznym dyskursie medycznym, moralnym i psychiatrycznym. Od czasu Anatomy of Melancholy Roberta Burtona z 1621 r. średniowieczna i renesansowa teoria „humorów” zadomowiła się w angielskiej refleksji nad narodową, jednostkową i zbiorową „medyczną” psychologią ${ }^{16}$. Na początku XVIII w. w traktacie Treatise of

15 „Tuesday 11 Sept. At the sessions in Old Bailey [--] two prisoners were capitally convicted, viz. John Dempsey, a sailor for murdering John Perry near Ratcliffe highway by striking him on the head with a large stick through one of the ends thereof was driven several long nails which penetrated his skull, and William Odell, a soldier for murder of his wife [--] by strangling her and afterwards cutting her in several parts with his sword and throwing her into a clay-pit”, „Gentleman's Magazine” 30, 1760, s. 440. Por. D.A. Kent, „Gone for a Soldier”. Family Breakdown and the Demography of Desertion in a London Parish, 1750-1791, „Local Population Studies” 45, 1990, s. 27-45.

16 Podstawowym opracowaniem pozostaje L. Babb, Sanity in Bedlam. A Study of Robert Burton's Anatomy of Melancholy, East Lansing 1959. 
the Spleen and Vapours (z 1725 r.) Richard Blackmore uznał melancholię „hipochondryczne i histeryczne przypadłości, potocznie zwane śledziennictwem (spleen)" - za chorobę o możliwych śmiertelnych skutkach. W 1733 r. znany lekarz Richard Cheyne poszedł jeszcze dalej i w traktacie The English Malady uznał tę przypadłości - wywołaną dostatkiem życia codziennego, siedzącym trybem życia oraz wilgotnym klimatem - za groźną przypadłość narodową ${ }^{17}$. Angielskie wcielenie Argana z Molierowskiego Chorego $z$ urojenia znalazło swój prawdziwy dom i pełną realizację w dramatach (np. sztuce Georga Colemana The Spleen z 1776 r.), powieściach (np. Tobiasa Smolletta), eseistyce (Oliver Goldsmith w The Citizen of the World), poezji i przede wszystkim refleksji medycznej XVIII w. W tym ostatnim wymiarze badania Jonathana Andrews i Andrew Skulla, wykorzystujące m.in. medyczne notatki doktora Johna Monro (1715-1791), głównego lekarza londyńskiego szpitala betlejemskiego (tzw. Bedlam, co stało się słowem używanym jako synonim szaleństwa), który po $1766 \mathrm{r}$. spisywał swoje obserwacje (ponad 100 przypadków), pozwoliły na określenie, w jaki sposób oceniano przypadki dotyczące umysłowo chorych, gdzie kończyły się obiegowe diagnozy, a zaczynała nowożytna medyczna refleksja, jakie przypadki uważano za nieuleczalne (i dlaczego), a komu dawano (i jakie) nadzieje na wyzdrowienie ${ }^{18}$.

Stirn obracał się w środowisku lekarzy, ludzi, których wiedza i wykonywany zawód były poszukiwane oraz przynosiły finansową stabilizację. Jego ofiarą był 27-letni chirurg (i położnik), „który reklamował lekarstwa na fistuły i inne podobne choroby"19. Uznanie Stirna za

17 O. Doughty, The English Malady of the Eighteenth Century, „The Review of English Studies" 2, 1926, s. 257-269.

${ }_{18}$ Motyw melancholii w literaturze angielskiej omawiali m.in. M. Byrd, Visits to Bedlam. Madness and Literature in the Eighteenth Century, Columbia South Car. 1974; M.V. DePorte, Nightmares and Hobbyhorses. Swift, Sterne, and Augustan Ideas of Madness, San Marino Ca. 1974. Dla badań nad medycznymi kwalifikacjami chorób umysłowych w XVIII w. podstawowe znaczenia mają Medical Fringe and Medical Orthodoxy, 1750-1850, red. W.F. Bynum, R. Porter, London 1986; W.Ll. Parry-Jones, The Trade in Lunacy. A Study of Private Madhouses in England and Wales in the Eighteenth and Nineteenth Centuries, London 1972; R.A. Houston, Madness and Society in Eighteenth-Century Scotland, Oxford 2000; J.P. Eigen, Witnessing Insanity. Madness and Mad-Doctors in the English Court, New Haven, Conn. 1995; M. MacDonald, Lunatics and the State in Georgian England, „Social History of Medicine” 2, 1989, 3, s. 299-313; J. Andrews, A. Scull, Undertaker of the Mind. John Monro and Mad-Doctoring in Eighteenth-Century England, Berkeley Ca. 2001; iidem, Customers and Patrons of the Mad-Trade. The Management of Lunacy in Eighteenth-Century London, Berkeley Ca. 2003.

19 „while he lived with Mr. Crawford he became acquainted with Mr. Matthews, a surgeon in the neighbourhood who advertised the cure for fistulas and other disorders of the like kind”, „Gentleman's Magazine” 30, 1760, s. 400. O obu profesjach Matthewsa pisano w „London Magazine” 29, 1760, s. 434. O najsłynniejszej akuszerce Francji i autorce 
niepoczytalnego - możliwość, którą sam najpierw odrzucił, a potem próbował wykorzystać - było o tyle istotne, że zmieniało w zasadniczy sposób kwalifikację jego czynu. Podsądny uznany za obłąkanego nie podlegał karze, najczęściej wracał pod opiekę rodziny, parafii lub - jeśli rodzina miała na to pieniądze - trafiał do prywatnego zakładu zamkniętego. Prawo angielskie do 1800 r. (tzn. do przyjęcia ustawy Criminal Lunatics Act) nie przewidywało dla niego nawet szpitalnego odosobnienia (oddział dla umysłowo chorych przestępców otwarto w szpitalu betlejemskim dopiero w 1816 r., a osobny szpital powstał w 1864 r.). Richard Moran przypominał, że w okresie 1740-1800 londyński trybunał karny uniewinnił ok. 50 proc. oskarżonych, wobec których kwalifikacja prawna czynu (nawet kradzieży) była uzależniona od (niełatwej) do dowiedzenia niepoczytalności. Trzydzieści lat po procesie Stirna sądzono niejakiego Johna Fritha, który uważał się za św. Pawła i rzucił kamieniem w królewski powóz. Badanie lekarskie (przez królewskiego medyka) przyniosło opinię, że jest „zupełnym szaleńcem”. Odesłano go do więzienia (bez wydania wyroku) w oczekiwaniu, aż zostanie przeniesiony do zamkniętego zakładu ${ }^{20}$. Sąd usiłował ustalić ponad wszelką wątpliwość, czy Stirn popełnił morderstwo w stanie ograniczonej poczytalności. Jak wskazywał Stephan Landsman na podstawie analizy 174 spraw o morderstwo sądzonych w Londynie (w okresie 1717-1817), aż w 75 proc. procesów rolę ekspertów pełnili ludzie z medycznym wykształceniem, przede wszystkim chirurdzy. Nie oznaczało to jednak, że ich opinie miały automatycznie decydujące znaczenie dla ławy przysięgłych, która często bardziej ufała postronnym obserwatorom zajść, gotowym do przekazania powierzchownego opisu, ale niedysponującym żadną medyczną wiedzą $^{21}$. Także orzeczenia cząstkowe - opinie koronera i powołanych

podręcznika położnictwa pani du Coudray (czynnej w latach 1751-1783) zob. N.R. Gelbart, The King's Midwife. A History and Mystery of Madame du Coudray, Berkeley Ca. 1998.

${ }^{20}$ R. Moran, The Origin of Insanity as A Special Verdict. the Trial for Treason of James Hadfield (1800), „Law \& Society Review” 19, 1985, 3, s. 487-519 (przypadek Fritha, s. 510). W 1754 r. skazano na śmierć (za rozbój) Johna Haynesa, wykształconego robotnika (7 lat czeladniczego terminowania u kołodzieja), potem sklepikarza. Kapelanowi więziennemu przyznał się, że był nałogowym alkoholikiem pięciokrotnie zamykanym w domu dla obłąkanych z powodu nadużywania ginu („madness chiefly proceeded from drink”). Zob. OBSP, ref. nr OA17541209. Na temat dywagacji prawników, dotyczących przestępstw popełnionych pod wpływem upojenia alkoholowego (pijaństwo nie zwalniało jednak - jak obłęd - z odpowiedzialności) zob. D. Rabin, Drunkenness and Responsibility for Crime in the Eighteenth Century, „Journal of British Studies” 44, 2005, 3, s. 457-477.

${ }^{21} \mathrm{Na} 174$ sprawy 131 (75 proc.) dotyczyło morderstw, a pozostałe: gwałtu (także na nieletnich, 9 proc.) oraz dzieciobójstwa (10 proc.). Zob. S. Landsman, One Hundred Years of Rectitude. Medical Witnesses at the Old Bailey, 1717-1817, „Law \& History Review” 16, 
przez niego przysięgłych - wskazują w wielu przypadkach na „deficyt" wiedzy i niepewność. W przypadku młodego flisaka znad Tamizy, który latem 1772 r. uderzył „w napadzie pasji” swoją siostrę, a potem, skruszony, przebił się nożem, wydano - może zbyt pochopnie - wyrok braku poczytalności (lunacy), natomiast kolejny przypadek, nomen omen dotyczący pewnego Niemca, który napadł z zamiarem zabójstwa na panią Taafe, żonę golibrody, u której wynajmował stancję, postawił przed urzędnikami inne, ale także trudne pytania. Niemiec poderżnął sobie gardło i koroner nie miał wątpliwości, że to felo de se - samobójstwo. W jego kieszeni znaleziono list, napisany do przysięgłych, w którym nie przyznawał się do chęci mordu, a jedynie „naznaczenia” swojej gospodyni (czy nożem?) i pisał „panowie, nie kłopoczcie się, byłem przy zdrowych zmysłach, kiedy popełniłem ten czyn". Powodem agresji - podobnym do przypadku Stirna - było wymówienie mu mieszkania $^{22}$. Czy jednak list samobójcy i jego deklaracja trzeźwego umysłu nie były tylko potwierdzeniem poważnych zaburzeń emocjonalnych?

Sam wygląd oskarżonego Stirna - sprowadzonego na rozprawę z więzienia, w którym podjął głodówkę - mógł już budzić wątpliwości: zamiast czarnego ubrania (w jakim wystąpił w czasie przesłuchania dwa dni wcześniej, 10 września), „pojawił się w zielonej koszuli nocnej [--] wcześniej doradzono mu, aby udawał szaleństwo, ale radę tę odrzucił z pogardą [--] często mdlał, zezwolono mu więc usiąść i posilić się, a kiedy zapadł wyrok, zasłabł zupełnie"23. Świadek Crawford zeznawał, że

1998, 3, s. 445-494. Por. T.R. Forbes, Surgeons at the Bailey. English Forensic Medicine to 1878, New Haven Conn. 1985. Na temat dzieciobójstwa zob. P.C. Hoffer, N.E.H. Hull, „Murdering Mothers". Infanticide in England and New England, 1558-1803, New York 1981; R.K. McClure, Coram's Children. The London Foundling Hospital in the Eighteenth Century, London 1981. Na temat trudności w kwalifikacji gwałtu: A.E. Simpson, Popular Perceptions of Rape as a Capital Crime in Eighteenth-Century England. The Press and the Trial of Francis Charteris in the Old Bailey, February 1730, „Law \& History Review” 22, 2004, 1, s. 27-70; A. Wilson, Illegitimacy and Its Implications in Mid-Eighteenth Century London, "Continuity \& Change" 4, 1989, 1, s. 103-164; T. Hitchcock, „Unlawfully Begotten on Her Body”. Illegitimacy and the Parish Poor in St. Luke's Chelsea, w: Chronicling Poverty. The Voices and Strategies of the English Poor, 1640-1840, red. T. Hitchcock, P. King, P. Sharpe, London 1997, s. 70-87. Przykładem bardzo podobnym do sprawy Stirna był casus Williama Franklanda z 1774 r., biznesmana nieudacznika, który usiłował zastrzelić w oberży pełnej ludzi urzędnika miejskiego. W czasie procesu jego prawnik wezwał wielu „niemedycznych” świadków (budowniczego szpinetów, prawnika, krawca, służącego oskarżonego, oficera), którzy dowodzili, że oskarżony jest ekscentrycznym i nieobliczalnym szaleńcem. Sąd nie uległ ich argumentom i skazał Franklanda na śmierć, zob. OBSP, ref. nr 17740112-23 (dostęp 30 VI 2013).

22 „Gentleman's Magazine” 42, 1772, s. 340 (flisak), s. 489 (Niemiec).

23 "he was brought to the bar again but instead of his suit of black he appeared in a green night gown he had been advised to feign himself mad but this advice he 
w czasie ostrej już wymiany zdań w oberży podenerwowany Matthews nazwał Stirna łajdakiem i kazał mu wracać do jego „wszawego kraju”, a reszta zebranych głośno wołała, że jest wariatem i powinno się go zamknąć w szpitalu Bedlam. Sam świadek uważał Stirna za nieuleczalny przypadek emocjonalnego, ale tymczasowego niezrównoważenia, nie wahał się jednak używać terminu „szaleniec” i „wariat”. Crawford był jednak laikiem, choć z jego wypowiedzi wynika, że problematyka chorób (także szaleństwa) nie była mu zupełnie obca, a wiedza pochodziła zapewne $\mathrm{z}$ łatwo dostępnych lektur ${ }^{24}$. Na kilka lat przed rozpoznaniem przypadku Stirna w londyńskiej prasie przetoczyła się żywa polemika dotycząca chorób umysłowych, sformułowano - być może po raz pierwszy w angielskiej praktyce medycznej - nowe propozycje ich oceny, a ich pochodną było stopniowe traktowanie chorych w znacznie bardziej humanitarny sposób. Traktat doktora Williama Battie (1703-1776), naczelnego lekarza szpitala św. Łukasza, prywatnej instytucji dobroczynnej otwartej w 1751 r., krytykował praktyki stosowane w najstarszym i największym stołecznym szpitalu, czyli w Bedlam. Battie - któremu naczelny lekarz z Bedlam i czołowy autorytet w zakresie chorób umysłowych John Monro dał publiczny odpór - nie tylko potępiał zwyczaj sprzedawania biletów i pokazywania chorych jako turystycznej atrakcji oraz prób leczenia ich przypadłości zadawaniem bólu, ale przede wszystkim starał się swoim pacjentom (początkowo tylko 25 osobom) stworzyć w miarę wygodne, chroniące ich prywatność warunki pobytu oraz koncentrował się na somatycznych przyczynach szaleństwa, które chciał leczyć m.in. za pomocą kąpieli ${ }^{25}$. W procesie Stirna żaden $\mathrm{z}$ tych psychiatrycznych autorytetów osiemnastowiecznego Londynu nie pojawił się na sali sądowej.

rejected with disdain [--] he was often ready to faint he was therefore indulged with a seat and several refreshments, when sentence was passed upon him he quite fainted away”, „Gentleman's Magazine” 30, 1760, s. 403, o zielonej „nightgown” także „London Magazine” 29, 1760, s. 490. Na temat technik przesłuchań stosowanych w areszcie śledczym braci Fielding, instytucji, która w latach 1754-1780 spełniała rolę instancji „przedprocesowej”, zob. J.M. Beattie, Sir John Fielding and Public Justice. The Bow Street Magistrates' Court 1754-1780, „Law \& History Review” 25, 2007, 1, s. 61-100.

${ }^{24} \mathrm{Na}$ zjawisko „wiarygodnych laików” i niechęci wobec lekarzy zwracał uwagę S. Landsman, op. cit., s. $477 \mathrm{nn}$.

${ }^{25}$ A Treatise on Madness, London 1758. Publikacja kosztowała 2 szylingi 6 pensów, kwotę dość znaczną jak na ceny książek. Na temat obecności problematyki medycznej w prasie zob. m.in. H. Dingwall, „To Be Insert in the Mercury”. Medical Practitioners and the Press in Eighteenth-Century Edinburgh, „Social History of Medicine” 13, 2000, 1, s. 23-44. O kontrowersji Battie-Munro zob. A Treatise on Madness by William Battie M.D., and Remarks on Dr.Battie's Treatise on Madness by John Monro MD. A Psychiatric Controversy of the Eighteenth Century, wprow. R. Hunter, I. Macalpine, London 1962. 
Rola biegłego przypadła jednemu ze świadków, Samuelowi Chapmanowi, chirurgowi (a więc medykowi bez akademickiego stopnia), koledze po fachu i dobremu znajomemu ofiary (i mordercy), któremu zadawano bardzo szczegółowe pytania o jego ocenę stanu umysłu oskarżonego. Feralnego wieczoru obaj medycy udali się najpierw do „małego teatru" na Haymarket, a po przedstawieniu poszli na drinka do oberży Pewter Platter. Chapmana pytano, czy w zachowaniu Stirna, którego często gościł we własnym domu, dostrzegał ślady szaleństwa (insanity), czy rozpoznawał u niego odruchy samobójcze oraz czy jego zachowanie znamionowało działania osoby niepoczytalnej (act of lunacy). Chirurg początkowo zarzekał się, że przypadki podobnych zaburzeń - czasowe zaćmienia umysłu - nie są mu profesjonalnie znane („nigdy nie leczyłem wariata” - podkreślał) i że nie zna też lekarstwa na „lekkie obłąkanie", tzn. przypadki periodycznych napadów, stanu, który określił terminem „niemedycznym” jako „rozpacz”, w końcu jednak - przynaglany do udzielenia wiążącej odpowiedzi - stwierdził, że „wedle jego wiedzy nie sądzi, aby [Stirn] był wariatem (mad man)"26. Tym razem sąd zaufał orzeczeniu lekarza, a tym samym los podsądnego został - zdawało się przypieczętowany.

Po wysłuchaniu wyroku Stirn zwrócił się z prośbą do sądu, aby na miejsce egzekucji mógł udać się powozem. Przywilej ten dotyczył tylko rzadkich - umotywowanych albo statusem społecznym, albo szczególnymi okolicznościami - sytuacji, sąd wyjaśnił więc skazanemu, że „było jego zamiarem, aby takich zbrodniarzy ukazać na widok publiczny i przerazić wszystkich, aby nie popełnili obmierzłej zbrodni morderstwa" ${ }^{27}$. Ten moment procesu wymaga dodatkowej uwagi. Praktyka dydaktycznego „odstraszania” za pomocą dokładnie zaplanowanych publicznych „teatrów skruchy”, aprobowana przez londyński trybunał, została już wielokrotnie przeanalizowana i nie wymaga głębszej refleksji ${ }^{28}$. Stirn domagał się szczególnego prawa: z jednej strony do anonimowości we wnętrzu powozu, którym pośród szpaleru zebranych gapiów wieziono go

${ }^{26}$ OBSP, ref. nr 17600910-19, s. 3, 10-11, 14. Zob. S. Landsman, op. cit., s. 546 nn. Por. R.A. Houston, Courts, Doctors and Insanity Defences in $18^{\text {th }}$ and $19^{\text {th }}$ Century Scotland, „International Journal of Law \& Psychiatry” 26, 2003, 4, s. 339-354.

${ }^{27}$ "Stirn than begged he might be permitted the use of coach to the place of execution, which the court denied, and told him, it was the intention of the legislature that such criminals should be exposed to publick view as a terror to all persons, that they should not be guilty of the horrid crime of murder”, „London Magazine” 29, 1760, s. 490.

28 P.T. Dobrowolski, Powozem na szafot. Teatry skruchy w osiemnastowiecznym Londynie, KH 120, 2013, 3, s. 425-447. Wersja angielska: By Coach to the Scaffold. Theatres of Remorse in Eighteenth-Century London, KH 121, 2014, Special Issue, s. 71-93. 
pod szubienicę, z drugiej, do zaliczenia go do przestępców szczególnych, którzy na miejsce kaźni podróżowali tak, aby już sam przywilej zwrócił dodatkową uwagę. Pospolici przestępcy jechali na Tyburn wszyscy razem na jednym wózku, widoczni dla licznie zebranej gawiedzi. Trudno orzec, czy Stirn pamiętał o przypadku, który kilka miesięcy wcześniej przykuł uwagę londyńskiej opinii publicznej. Rankiem 5 maja 1760 r. przez Londyn przejechała kawalkada powozów i eskorty, w której najważniejszym pojazdem był sześciokonny landau lorda Ferrers, brutala i alkoholika, który podążał tym wykwintnym pojazdem (swoim) na szubienicę, skazany za zastrzelenie swego służącego ${ }^{29}$. Ostatniego powieszonego za pospolite przestępstwo para Anglii nie należy oczywiście porównywać $\mathrm{z}$ niemieckim imigrantem, chociaż $\mathrm{w}$ obu sprawach przewijał się ten sam motyw obrony, tzn. możliwość dowiedzenia im niepoczytalności w chwili popełnienia zbrodni. Stirn domagał się aż tak znaczącego przywileju, ponieważ oczekiwanie, że na śmierć uda się powozem - inaczej niż dwaj pospolici mordercy skazani wraz z nim - mieściło się w jego rozumieniu poczucia honoru, pojęcia, które w całym jego złożonym portrecie psychologicznym i motywacjach jego czynów odgrywało kluczową rolę. W podobnym „porządku myślenia” mógł mieścić się zakup pary pistoletów. Jedna z relacji prasowych sugerowała (nie do końca zgodnie z zeznaniami pomocnika rusznikarza), że „kupił je, załadował i posłał panu Matthews wyzwanie, którego ów nie przyjął. Możliwe, że od tego czasu zdecydował się zabić, nie mając już innego narzędzia zemsty"30.

Odniesienie do pojedynku - pomijając już dość szczególny „społeczno-towarzyski" wymiar tak planowanego spektaklu, tzn. strzelanie się kalwińskiego duchownego z chirurgiem - przenosi nas w przestrzeń znaczeń i społecznej symboliki wyznaczoną pojęciem osiemnastowiecznego angielskiego honoru i jego publicznych manifestacji. Należy zaznaczyć, że pojedynki z użyciem broni - przede wszystkim pistoletów, ponieważ biała broń wyszła z mody z połowie wieku - należały do „etosu wojskowego", były surogatem pokazu bitewnej odwagi i, jak dowodził Robert Shoemaker, traciły już w XVIII w. społeczne przyzwolenie. Niechętnie tolerowane nadal $\mathrm{w}$ przypadku oficerów, napotykały rosnącą niechęć opinii publicznej. Honor i jego manifestacje - pisali polemiści - nie polega na krwawym sporcie szlachetnie urodzonych (lub - jak żołnierze - „zawodowo zobligowanych” do takiego pokazu), jest wartością

${ }^{29}$ Streszczenie sprawy w: http://www.exclassics.com/newgate/ng284.htm.

30 „Stirn bought a pair of pistols and that having loaded them he sent Mr.Matthews a challenge which Matthews refused to accept, an it is probable that from that time he resolved upon the murder no other mean of revenge being left him”, „Gentleman's Magazine" 30, 1760, s. 402. 
wewnętrzną, pochodną cnoty, która odrzuca wszelkie przejawy agre$\mathrm{sji}^{31}$. Nie odwołując się do bogatej refleksji socjologicznej dotyczącej uwarunkowań pojęcia honoru - i reputacji - którą nakreśliły badania Johna G. Peristiany czy Juliana Pitt-Riversa, łatwo dostrzec, że naruszenie „honoru” Stirna - jakości, o której tyle mówił - wynikało z zagrożenia, jakie dla jego reputacji niosły narzucone mu warunki pracy: inteligenta-wyrobnika rzuconego w obce mu (mimo początkowej sympatii innych) środowisko ${ }^{32}$. Zachowania Niemca tłumaczyć można poprzez zjawisko „agresji w miejscu pracy" (workplace aggression), które socjologowie wiązali z poczuciem zagrożenia własnej wartości i z obrazą poczucia godności.

31 „Gentleman's Magazine” podawał, że w sobotę 13 maja 1769 r. „dwóch gentelmanów stoczyło pojedynek w Hyde Parku z powodu kłótni w Vauxhall, jeden otrzymał pchnięcie w prawe ramię, drugi został trafiony w udo po czym rozdzielili ich sekundanci”, „Gentleman's Magazine” 39, 1769, s. 269. W dniu 3 lutego 1773 r. na polach Marylebone strzelali się lord George Townshend (z zawodu żołnierz) i Charles Coote hr. Bellomont, który otrzymał ciężką ranę. Zasady „grzeczności” były jednak respektowane, co relacjonowano w: „Universal Magazine” 52, 1773, s. 105-106 i „London Magazine" 42, 1773, s. 97-98. Po kłótni w tawernie Star and Garter przy Pall Mall doszło do pojedynku, w wyniku którego zmarł żałowany przez gazetę p. Chaworth, a jego zabójca lord Byron stanął przed Izbą Lordów. Sprawa była gruntownie opisywana, zob. „Gentleman's Magazine” 35, 1765, s. 45, 143, 196, 227-229, oraz w „Universal Magazine” 36, 1765, s. 220 . W oberży Adelphi na Strand 14 stycznia 1777 r. w zamkniętym pokoju strzelali się (o honor kobiety) redaktor „Morning Post” Bate oraz kpt. Stony. Obaj chybili i chwycili za białą broń, zob. relacje w „Gentleman's Magazine” 47, 1777, s. 43. Inny pojedynek oficerów na pistolety, ibidem 35, 1765, s. 441. „London Magazine” (43, 1774, s. 46) relacjonował pojedynek oficerski w Irlandii z powodu zarzucenia jednemu z uczestników, że ,jest Cyganem”. James E. Fox, który strzelał się 29 listopada 1779 r. w Hyde Parku z posłem do Izby Williamem Adamem, został lekko ranny i stwierdził: „Bez wątpienia bym zginął, gdyby Pan Adam używał innego niż rządowy prochu” za: A. Sherbo, From the Westminster Magazine. Swift, Goldsmith, Garrick, Et Al., „Studies in Bibliography" 41, 1988, s. 274. Szermierkę propagowano jako sztukę obronną, należącą do ekwipunku wykształconego szlachcica. Szkołę fechtunku założył w Londynie w 1763 r. Włoch Domenico Angelo, autor L'ecole des armes (1763), zob. R.B. Shoemaker, The Taming of the Duel. Masculinity, Honour, and the Ritual Violence in London, 1660-1800, "The Historical Journal" 45, 2002, s. 525-545, zwł. 530; D. Andrew, The Code of Honour and its Critics. The Oposition to Duelling in England, 1700-1850, „Social History” 5, 1980, s. 409-434. Por. J. Beattie, op. cit., s. $91 \mathrm{nn}$. Na temat ewolucji postaw wokół pojedynków zob. też Men and Violence. Gender, Honor, and Rituals in Modern England and America, red. P. Spierenburg, Columbus Oh 1998; M. Peltonen, The Duel in Early Modern England. Civility, Politeness and Honour, New York 2003.

32 Mediterranean Countrymen. Essays in the Social Anthropology of the Mediterranean, red. J. Pitt-Rivers, Paris 1964; Honour and Shame. The Values of the Mediterranean Society, red. J.G. Peristiany, Chicago 1966. Zob. przegląd badań: V. Baxter, A.V. Margavio, Honor, Status, and Aggression in Economic Exchange, „Sociological Theory” 18, 2000, 3, s. 399-416. 
Poruszamy się blisko innej, już „mieszczańskiej” koncepcji honoru, w której - jak dowodził John Smail - nad potępianą eksplozją wojowniczych emocji przeważało poczucie szukania kompromisu, unikania gwałtownych poczynań, obrona własnej reputacji - męskiej, kupieckiej, handlowej - za pomocą codziennych "godnych" zachowań. Stirn chciał się „po szlachecku” strzelać, Matthews - po „mieszczańsku” odmówił ${ }^{33}$.

Meandry umysłu Stirna oraz nieporozumienia między nim, a jego dwoma kolejnymi dobroczyńcami i gospodarzami zaowocowały przekonaniem, że wszyscy spiskują przeciw niemu, że w zmowie (combination) chcą zrujnować jego reputację i zmusić go do wyjazdu z Anglii. Rozpowiadał - choć nie ma na to żadnych dowodów - że Matthews „niesprawiedliwie i jak łotr oskarżył go o pozbawienie go uczucia żony i wyłudzenie od niej pieniędzy” - a także „o kradzież i cudzołóstwo”, jak dodawał jeden ze świadków w czasie procesu. Niemiec twierdził też, że wyrzucono go z domu ,jak zbója i nikczemnika”, oraz że ,jego honor został zraniony, reputacja zupełnie zrujnowana, stracił też utrzymanie i w takich warunkach żyć nie będzie". William Watts, dzielnicowy (constable), którego wezwano na miejsce zbrodni i który zatrzymał („za kołnierz") Stirna, usłyszał jego przyznanie się do popełnienia morderstwa oraz wytłumaczenie, że „pan Matthews zranił jego honor, który jest dlań droższy niż życie i że żałuje tylko, iż sam się nie zastrzelił"34.

\section{Samobójca}

Świadkowie bardzo wiele miejsca poświęcili wyrażeniu swojej troski o oskarżonego, który - w ich mniemaniu - gotów był targnąć się na własne życie. Raport kapelana więzienia w Newgate, w którym Niemiec oczekiwał na wykonanie wyroku, wspominał, że „tak bardzo był zdeterminowany, żeby się zabić, iż powiedział, że jeśli nic innego nie

${ }^{33}$ J. Smail, Credit, Risk, and Honour in Eighteenth-Century Commerce, ,Journal of British Studies” 44, 2005, 3, s. 439-456. Por. E. Foyster, „Boys Will be Boys?” Manhood and Aggression, 1660-1800, w: English Masculinities 1660-1800, red. T. Hitchcock, M. Cohen, Harlow 1999, s. 151-166; F. Dabhoiwala, The Construction of Honour, Reputation and Status in Late Seventeenth- and Early Eighteenth-Century England, "Transactions of the Royal Historical Society" 6 ser., 6, 1996, s. 201-213; R. Shoemaker, Reforming Public Manners: Public Insult and the Decline of Violence in London, 1660-1740, w: English Masculinities, s. 133-150.

34 „he had been turned out of the house like a villain and scoundrel”. Zeznanie W. Wattsa: ,he said, his honour was wounded by Mr.Matthews, which was dearer to him than his life, and that he was only sorry he had not shot himself”, „Universal Magazine" 27, 1760, s. 153-153; OBSP, ref. nr 17600910-19. 
pomoże to albo wyrwie sobie serce, albo rozbije głowę, a nie pójdzie na szubienicę". Lęk przed niegodną śmiercią spowodował, że Stirn podjął w więzieniu głodówkę (przyjmował jednak „miskę lub dwie kawy i trochę wina”). Zatroskany osłabieniem więźnia duchowny pouczał go, iż „samobójstwem większą ściągnie [na siebie] infamię niż przez powieszenie, ponieważ jego ciało będzie włóczone, jak ścierwo zwierzęce do wykopanej dziury na rozstajach, a potem wbiją w nie kołek"35. Zapowiedziana skazańcowi gradacja infamii jest niezwykle interesująca: na pierwszy rzut oka wskazuje, że śmierć przez powieszenie - znana wszystkim z sentencji wyroku - była dla kapelana i więziennych strażników, wyrazicieli powszechnej w tym przypadku opinii, karą społecznie akceptowaną, niejako naturalną i nieobciążoną dodatkowym piętnem. Przestępcę-wisielca traktowano jako znak wypełnienia się racjonalnie uzasadnionej przez prawo procedury wymierzania sprawiedliwości, a jego ciało (nawet - jak stanowił wyrok - po przekazaniu go chirurgom w celu przeprowadzenia sekcji) zwracano bliskim lub rodzinie w celu pogrzebania, natomiast samobójcę traktowano jako przypadek szczególny, „nienaturalny” i jako oznakę bezbożnego tchórzostwa ${ }^{36}$.

Ostatnie chwile Niemca w londyńskim więzieniu są dość niejasne. Wedle jednej z relacji, w oczekiwaniu na wykonanie wyroku - Stirna skazano w piątek, a przepisy stanowiły, że egzekucja nie może odbyć się w niedzielę - więźnia odwiedziło dwóch jego rodaków (duchownych?), którzy chcieli się z nim pomodlić. Niedługo potem znaleziono go skręcającego się z bólu i mimo interwencji wezwanego aptekarza (puścił mu krew) i chirurga (starał się wywołać torsje) więzień zmarł po kilku godzinach „,in great agony”. Przy łóżku znaleziono kawałek opium „długi na cal”. Nie umiemy do końca odpowiedzieć na pytanie, czy Stirn został otruty (lub skłoniony do tego), czy może raczej sam zażył przyniesioną mu truciznę. Następnego dnia wieczorem - w sobotę 13 września 1760 r. - koroner wydał werdykt: samobójca. Stirn umknął katu.

35 „so fixed was his determination to destroy himself that he said, if no other means would do he would either tear out his heart or beat his brains out rather than go to the gallows”, Ordinary of Newgate Account, wydrukowany w „Universal Magazine” 27,1760 , s. 155-158; „he was [--] urged to eat [--] for he was told that he would incur more infamy by suicide than by hanging, as his body would be dragged as that of a brute to a hole dug to receive it at the crossroads and a stake would be afterwards driven thro'it”, „Gentleman's Magazine” 30, 1760, s. 403 n. Opis ostatnich chwil Stirna w „London Magazine” 29, 1760, s. 490.

${ }^{36}$ Zob. A. McKenzie, „This Death Some Strong and Stout Hearted Men Doth Choose”. The Practice of „Peine Forte et Dure” in Seventeenth- and Eighteenth-Century England, „Law \& History Review" 23, 2005, 2, s. 293 n., 304 nn. 
Samobójstwo należy do jednego z żywo przez historyków dyskutowanych zjawisk kulturowych. Badania Jeffreya Watta, Michaela MacDonalda i Donny Andrew podejmowały temat prawnej i społecznej ewolucji ocen aktu targnięcia się na własne życie, jaka miała miejsce we wczesnonowożytnej Anglii i Europie. Oświecenie - tu historycy są zgodni - dekryminalizowało samobójstwo, sądy coraz częściej nie skazywały już samobójców jako felones de se na przepadek mienia (ku rozpaczy ich rodzin, choć formalnie dopiero od $1823 \mathrm{r}$.) i na poniżający pochówek, nie dostrzegały wcześniejszej, motywowanej argumentami teologów interpretacji, która podkreślała „diabelską inspirację” samego czynu, skłaniały się ku wykładni medycznej - non campos mentis - uznając nastrój „melancholijny" (jeden ze stanów Stirna) i psychologiczne oraz medyczne przyczyny za powód zadania sobie śmierci ${ }^{37}$. Na temat powodu samobójstw umiano nawet żartować. W eseju opublikowanym w 1755 r. anonimowy autor wskazywał na przyczyny, wymieniając m.in. wyścigi w Newmarket (tzn. bankructwa po przegranych), koszt posiadania utrzymanki, podróże do Francji i Włoch (czy wskutek kulturowego szoku?), przegrane w wyborach do Izby Gmin, jedzenie potraw przygotowywanych przez francuskich kucharzy oraz francuską chorobę (esej powstał w przededniu wojny z Francją, która uczyniła ze Stirna emigranta ${ }^{38}$. Niemiec nie doczekał się jednak wpisania do żadnej z takich kategorii. Orzeczenie koronera skazało go na znaną już dużo wcześniej - sięgającą pogańskich rytów procedurę przebicia ciała drewnianym kołkiem - aby duch potępieńca nie gnębił żyjących, oraz na wywiezienie trupa na odludzie i pogrzebanie w niepoświęconej ziemi. Więzienny kapelan zrelacjonował ten rytuał z kronikarską dokładnością ${ }^{39}$.

${ }^{37} \mathrm{Na}$ temat symboliki osiemnasto- i dziewiętnastowiecznych pogrzebów (oraz praktyk grabarzy i zakładów pogrzebowych) zob. T. Laqueur, Bodies, Death and Pauper Funerals, „Representations” 1, 1983, s. 109-131. Por. M. MacDonald, The Medicalization of Suicide in England. Laymen, Physicians, and Cultural Change, 1500-1870, „The Milbank Quarterly" 67, 1989, s. 69-91; M. MacDonald, T.R. Murphy, Sleepless Souls. Suicide in Early Modern England, Oxford 1990; D. Andrew, Debate. The Secularization of Suicide in England 1660-1800, „Past \& Present” 119, 1988, s. 158-165; J. Merrick, Patterns and Prosecution of Suicide in Eighteenth-Century Paris, „Historical Reflections” 16, 1989, s. 1-53; From Sin to Insanity. Suicide in Early Modern Europe, red. J.R.Watt, Ithaca 2004; J.R. Watt, Choosing Death. Suicide and Calvinism in Early Modern Geneva, Kirksville 2000. Przegląd badań (niemieckich i anglosaskich) w: R. Healy, Suicide in Early Modern and Modern Europe, „The Historical Journal" 49, 2006, s. 903-919.

38 „London Magazine” 24,1755, s. 22-24.

39 „soon after he was dead an inquisition was taken before Thomas Beach esq. coroner of the City of London and after the examination of three hours Stirn was found guilty of self-murder and a warrant was issued for him to be buried at the public 
Sprawę Stirna analizowaliśmy jako postać „społecznego dramatu” osadzonego w środowisku wielkomiejskiej inteligencji. Jego trzy akty: morderstwo, szaleństwo i samobójstwo ukazują interakcje dynamicznie przenikających się systemów wartości i zasługują na próbę podsumowania.

Zastrzelony lekarz, ale również jego morderca, okazują się ofiarami plotki, zjawiska, któremu antropologia kultury poświęciła wiele miejsca, uznając w niej m.in. społecznie potrzebny mechanizm monitorujący więzi grupowe i wymuszający stosowanie norm społecznych. Stirn posądzał Matthewsa i Crawforda o oczernianie jego reputacji, opowieści o jego ekstrawertycznym zachowaniu krążyły wśród znajomych, wracając do niego i nabierając nowego, groźniejszego kształtu. W odległym tle rzekomych oskarżeń pojawił się także zarzut o posądzenie go o cudzołóstwo, a w czasie ostatniej kłótni w oberży Stirn nagle zadeklarował, że nigdy nie cierpiał na chorobę weneryczną ${ }^{40}$. Czy w domu lekarza pojawiły się zatem napięcia między młodym lokatorem a żoną jego gospodarza? Świadek John Warford, który brał udział w zatrzymaniu mordercy zeznał, że w czasie kłótni w oberży Matthews, oburzony oskarżeniem o złe traktowanie lokatora, nazwał Stirna niewdzięcznikiem i wypomniał, iż „biegał po schodach za jego żoną”, na co Niemiec miał powiedzieć, że „pan sam nazwał żonę kurwą”. Wątek seksualnych napięć domowników nie występuje w innych relacjach o wydarzeniu i nie był eksploatowany przez prasę, można go jednak zaliczyć do „standardowego" tropu męskich lęków seksualnych. Wyimaginowane zarzucanie mu nieobyczajności i agresji w zachowaniu komponowało się w syndrom urażonego honoru i zniszczonego przez innych dobrego imienia.

W sprawie Stirna kluczowe znaczenie zajmują słowa, zapis rozprawy posługuje się cytatami w pierwszej osobie. Wypowiedzi protagonistów odtwarzają i tworzą określone sytuacje i stany napięcia. Mikrodramat, który opisują, rozgrywał się w dwóch przestrzeniach: prywatnych domach, gdzie Stirn był lokatorem, oraz w tak ważnych dla genezy angielskiej kultury miejskiej kawiarniach i oberżach. Słowa - także te agresywne i wulgarne - przypisywały się do określonej i kulturowo naznaczonej przestrzeni. W mieszkaniu Matthewsa próbowano - także ze względu na obecność kobiet - uniknąć kłótni i chirurg ostrzegał podenerwowanego Niemca, „aby uważał co mówi, bo dość już powiedział,

highway, but as his sentence was to be anatomized he was accordingly carried to the surgeons hall in the Old Bailey and his corpse afterwards was buried near Black-mary's hole with a stake driven through his body", Ordinary of Newgate Account, s. 158.

${ }^{40}$ Pojęciem pox od XVI w. określano syfilis, zob. K.P. Sienna, Pollution, Promiscuity, and the Pox. English Venereology and the Early Modern Medical Discourse on Social and Sexual Danger, ,Journal of the History of Sexuality” 8, 1998, 4, s. 553-574. 
żeby go przywołać do porządku", w oberży, miejscu publicznym i w obecności kilkunastu osób (mężczyzn, także obcych), padły już inwektywy i obraźliwe słowa (np. o „wszawym kraju”), ale kiedy Stirn zarzucił mu pomówienie o cudzołóstwo i kradzież, Matthews kazał mu usiąść i milczeć oraz „nie zachowywać się demonstracyjnie w publicznym towarzystwie”. Świadkowie procesu rozróżniali prywatne „mówienie w domu” od „publicznego”, w kawiarniach i oberżach, miejscach, które John Birrell opisywał w kategoriach habermasowskiej sfery publicznej, przestrzeni interakcji obszarów indywidualnej ekspresji i normy regulującej zbiorowe zachowania ${ }^{41}$.

Przez krótki czas sprawa Stirna znajdowała się w centrum zainteresowania londyńczyków. Obok doniesień prasowych uwagę przyciągała relacja kapelana z Newgate (tj. więziennego), osobiste i szczegółowe sprawozdanie o zachowaniu i ostatnich chwilach skazańca. Tekst - dobrze napisany - nie powstał (tak jak broszura Crawforda) na „specjalne zamówienie" jako produkt chwili, lecz należał do specyficznego i seryjnie produkowanego gatunku angielskiej literatury. Od drugiej połowy XVII w. londyńskie drukarnie regularnie wydawały nie tylko sprawozdania z procesów (tzw. Session Papers), ale także relacje urzędowego duchownego zatrudnionego w więzieniu. Początkowo były to jednokartkowe

${ }^{41}$ OBSP, ref. nr 17600910-19: „Mr.Matthews desired him to take care what he said, for he had already said enough for him to lay him by the heels”, s. 2-3; , and you yourself called your wife whore”, s. 5; „Mr. Matthews desir'd him not to expose himself in public company", s. 6. Funkcjonowanie plotki (ustnej i spisanej) w kontekście XVIII w. analizował Jason M. Kelly, Riots, Revelries, and Rumor. Libertinism and Masculine Association in Enlightenment London, „Journal of British Studies” 45, 2006, 4, s. 759-795, zwł. s. 763 nn. Por. R.B. Shoemaker, The Decline of Public Insult in London 1660-1800, „Past \& Present” 169, 2000, s. 97-131. O wulgaryzmach w języku potocznym zob. J. Sorensen, Vulgar Tongues. Canting Dictionaries and the Language of the People in Eighteenth-Century Britain, „Eighteenth-Century Studies" 37, 2004, 3, s. 435-454. Na temat badań nad osiemnastowieczną seksualnością zob. przegląd K. Harvey, The Century of Sex? Gender, Bodies, and Sexuality in the Long Eighteenth Century, „The Historical Journal” 45, 2002, 4, s. 899-916. Nawiązanie do Habermasa dotyczy książki Jürgena Habermasa, The Structural Transformation of the Public Sphere. An Inquiry into a Category of Bourgeois Society, Cambridge Mass. 1989 (oryg. niem. 1962), s. 36. Dyskusja na temat zastosowania jego tez do zjawiska angielskiego (kawiarnianego) „dyskursu publicznego” w XVII-XVIII w. posiada już rozległą literaturę. Zob. S. Pincus, „Coffee Politicians Does Create”. Coffeehouses and Restoration Political Culture, "Journal of Modern History” 67, 1995, s. 807-834; L. Klein, Coffeehouse Civility, 1660-1714. An Aspect of Post-courtly Culture in England, „Huntingdon Library Quarterly” 59, 1997, 1, s. 30-51; P. Langford, British Politeness and the Progress of Western Manners: An Eighteenth-Century Enigma, „Transactions of the Royal Historical Society” 6 ser., 7, 1997, s. 53-72; H. Berry, Rethinking Politeness in Eighteenth Century England. Moll King's Coffee House and the Significance of „Flash Talk”, „Transactions of the Royal Historical Society” 6 ser., 11, 2001, s. 65-81; J. Barrell, op. cit., s. 206-232. 
obwieszczenia, skrótowe wykazy spraw i wyroków z podaniem nazwisk skazańców. Około 1720 r. relacje kapelana wydawano już jako kilkustronicowe broszury, a po 1730 r. oba sprawozdania osiągały czasem objętość po 50 stron każde. Wzmianki nabierały literackiej fabuły, stając się pożywką dla powieści kryminalnej, która znalazła własny krąg czytelniczy i zdobyła wielką popularność. Nie była to wyłącznie właściwość angielskiej literatury, by wspomnieć dwadzieścia tomów (wydawanych od $1734 \mathrm{r}$.) Causes célèbres et interessantes spisanych przez prawnika François Gayot de Pitavela dla francuskich czytelników - różnica polegała jednak, mówiąc najprościej, na fabularnym zamiarze autorów: Francuz koncentrował się na przypadkach wykorzystywania bliźnich, nadużycia zaufania i na oszustwach, autorzy angielscy - Daniel Defoe, autor czterech powieści kryminalnych jest najlepszym przykładem - pisali biografie i autobiografie wszelkiej maści przestępców, koncentrując się przede wszystkim na realistycznym opisie zbrodni, ukazaniu przestępstw oraz ich społecznych uwarunkowań.

Angielscy moraliści i obrońcy normy etycznej, której obecność uważali za warunek konieczny we wszelkich przejawach literackiej twórczości, szybko dostrzegli, że literatura jarmarczna - z takiego korzenia wyrastały „relacje więziennych kapelanów” - przenika współczesne im powieściopisarstwo i staje się zagrożeniem dla moralności „klas średnich", które rozczytują się w dziejach morderców, bandytów i złodziejek (najsłynniejsza - Moll Flanders - bohaterka powieści Defoe urodziła się w więzieniu Newgate!). Znawca tego gatunku, Lincoln B. Faller, szacował, że w okresie 1650-1800 w obiegu znajdowało się 5-6 tys. pojedynczych wydrukowanych relacji o bardziej, mniej lub zupełnie nieznanych kryminalistach, które świetnie się sprzedawały i czytały ${ }^{42}$. Relacja kapelana

${ }^{42}$ Źródło (The Ordinary of Newgate, His Account of the Behaviour, Confession and Dying Words of the Malefactors who were Executed at Tyburn) analizowali: P. Linebaugh, The Ordinary of Newgate and his Account, w: Crime in England 1550-1800, red. J.S. Cockburn, Princeton-London 1977, s. 246-270, oraz J.H. Langbein, op. cit., s. 263-316, zwł. s. 267-271. Por. L.J. Davis, Wicked Actions and Feigned Words. Criminals, Criminality and the Early English Novel, „Yale French Studies” 59, 1980, s. 106-118; M. Harris, Trials and Criminal Biographies. A Case Study in Distribution, w: Sale and Distribution of Books from 1700, red. R. Myers, M. Harris, Oxford 1982, s. 1-36; L.B. Faller, Criminal Opportunities in the Eighteenth Century. The "Ready-Made” Contexts of the Popular Literature of Crime, "Comparative Literature Studies” 24, 1987, 2, s. 120-145 (szacunek liczby tekstów, s. 122); idem, Turned to Account. The Forms and Functions of Criminal Biography in Late Seventeenth-and Early Eighteenth-Century England, Cambridge 1987; P. Rawlings, Drunks, Whores, and Idle Apprentices. Criminal Biographies of the Eighteenth Century, London 1992 (edycja pięciu „życiorysów przestępczych”, osób skazanych na powieszenie w okresie 1724-1763); H.-J. Lüsebrink, Kriminalität und Literatur im Frankreich des 18. Jahrhunderts, München 1983. 
(teksty były zarówno podpisane, jak i anonimowe) o więziennych losach i samobójstwie Stirna budowała - podobnie jak broszura Crawforda psychologiczną i etycznie zorientowaną narrację o rozterkach, cierpieniach i próbach udzielenia skazańcowi duchowej pociechy. Tekst nie jest oczywiście tak bogaty w opisy jak „wzorcowe” pod tym względem „kryminalne” powieści Defoe czy Henry'ego Fieldinga, posiada jednak także z racji mniejszej objętości - bardzo jasne, typowe dla oświeceniowej moralistyki przesłanie. Kapelan próbuje Stirna pogodzić z nieuchronnym wyrokiem, jest twórcą literackiej już fabuły, ale także w jej kontekście reprezentuje głos prawniczego i „systemowego establishmentu", który nakazywał, aby normy prawa były respektowane do końca i przez każdego. Obawa, że Stirn targnie się na swoje życie - i oszuka kata - martwiła kapelana, który, pisząc o swoim podopiecznym, uważnie dobierał słowa: „Nie bez podstaw sądzi się, że trucizna, którą ponoć się zabił, została mu obiecana lub ją otrzymał w dniu, kiedy zaczął przyjmować jedzenie, tj. w piątek 22 sierpnia, ponieważ słyszano, jak mówił, że gdyby nie przyniesiono mu pociechy, nigdy by nie jadł, a nawet ściśle pilnowany i obserwowany «za pieniądze zdobyłby truciznę» i zwykle przy takich okazjach wybuchał salwami śmiechu"43. Czytelnicy uważnie śledzili ostatni akt sprawy i musieli przyznać, że narrator mimo swojej czujności został ostatecznie wyprowadzony w pole. „Kiedy poszedłem odwiedzić go koło szóstej tego wieczoru, na dziedzińcu spotkałem kogoś, kto czekał na widzenie. Nazwał się niemieckim pastorem. [Stirn] leżał na łóżku i [--] moja obecność go zaniepokoiła, wyprosił z izby współmieszkańca pana Daniel, a do mnie powiedział: Za izbę sam płacę. Jaki masz tu interes myszkując podejrzliwie?". Kapelan wyszedł, a wezwany nagle po godzinie znalazł już więźnia w agoniii ${ }^{44}$.

43 „it is not without reason inferred that the poison with which he is believed to have destroyed himself was promised him, or in his possession the day he began to eat viz. Friday the 22 of August because he was heard to say that if he had not some comfort brought him he never would have eaten for that however strictly watched and guarded «he would have poison for money» and he usually burst into loud fits of laughter on such occasions", Ordinary of Newgate Account, s. 156.

44 „When I went to visit him about six in the same evening I met in the pressyard a person waiting to go up to him who said he was a German minister. He was now laying in his bed [--] seemed uneasy at my presence, he hussed his chamber fellow Mr. Daniel out of the room and than said to me I pay fro my room what business have you here, prying with your suspicions", ibidem, s. 157. W dalszym ciągu relacji kapelan nie mógł się zdecydować, czy to jego towarzysz wizyty (raz oszust-szarlatan, raz kwestarz) podał Stirnowi truciznę (opium): „It was than strongly suspected that a person who appeared as a German minister by the name of Stapel was more likely a quack who brought him his dose [--] However this may be I am since well informed that he is a minister from 
Samobójstwo okazało się dla niego - i wymiaru sprawiedliwości, w którym był jednym z ważnych trybów - rozstrzygnięciem niespodziewanym, ucieczką przed oczekiwaną przez wszystkich karą. Czy z fabularnego punktu widzenia opowieść o Stirnie - tak jak ją zrelacjonowano okazuje się niewypałem? Londyński czytelnik kryminalnych sprawozdań mógł czuć się zawiedziony. Sąsiedzi i znajomi Niemca, mieszkańcy okolic ogrodów Hattona i traktu Holborn, stracili możliwość oglądania przejazdu skazańca pod szubienice na Tyburn. Inni nie przeczytali - jak to miało miejsce $\mathrm{w}$ dziesiątkach innych relacji - że skruszony morderca, tuż przed założeniem mu sznura, wyznał skruchę i wygłosił budujące przemówienie do zebranego tłumu ${ }^{45}$.

W sprawie Stirna porządki „świecki” i „duchowy” wydają się nakładać na siebie i przenikać. Pierwszy dominuje w relacjach prasowych i w sprawozdaniu z samego procesu, gdzie centralne miejsce zajmuje dyskurs „medyczny”, próba ustalenia poczytalności sprawcy. Realizuje on typową fabułę kryminalną znaną z setek podobnych wzmianek i tekstów. Odniesienia religijne pojawiają się dopiero w relacji więziennego kapelana, który uporczywie - i bezskutecznie - starał się odwieść więźnia od samobójczych zamiarów. Język duchownego - zapewne świadectwo chęci dotarcia do „wielkomiejskiego" odbiorcy - jest tylko bladym odbiciem retorycznych popisów kaznodziejów, których tyrady towarzyszyły wyjazdowym sesjom londyńskich sędziów na prowincje (tzw. assizes), w czasie których - dwa razy do roku - wydawano wyroki na złoczyńców oczekujących na ostateczne słowo przedstawicieli królewskiego wymiaru sprawiedliwości. „Pod wpływem namiętności - mówił w Oxfordzie w 1735 r. kaznodzieja George Fothergill - człowiek, jak to dowiedziono, staje się niebezpieczną i niszczycielska istotą". Jak dowodził Randall McGowen, angielskie „kazania sądowe” XVIII w. zawierały przede

Prussia come to solicit a collection for his suffering countrymen", ibidem, s. 157. Według relacji w „London Magazine” (27, 1760, s. 490) towarzyszem celi był Macdonald, który trudnił się łapaniem złodziei: „About six in the afternoon two persons supposed to be Stirn's countrymen went to visit him in Newgate and desired Macdonald, the thieftaker (who was Mr.Stirn's chum or companion in gaol) to go down stairs while they prayed with him".

${ }^{45}$ Klasyczną już interpretację publicznej egzekucji w Anglii jako społecznego rytuału wzmacniającego normy i mechanizm kontroli społecznej (wykorzystującą inspiracje Michaela Foucault) zainicjował James A. Sharpe, Last Dying Speeches. Religion, Ideology and Public Execution in Seventeenth-Century England, „Past \& Present” 107, 1984, s. 144-167. O innej strategii wykorzystywania tekstów sądowych (we Francji) zob. H.-J. Lüsebrink, L'Innocence persecutée et ses avocats. Rhetorique et impact public du discours "sensible" dans la France du XVIIIe siècle, "Revue d'histoire moderne et contemporaine” 40, 1993, 1, s. $86-101$. 
wszystkim apel o surowe, bezlitosne tępienie zła, wieszanie w imię surowych praw boskich, po to, aby maluczcy zrozumieli otchłań nieszczęścia, w którą popadną, popełniając przestępstwa. Duchowni uznawali, że surowe karanie złoczyńców - zgodne z wyrokami świeckich sądów było rękojmią utrzymania w ryzach bezbożnych i zdemoralizowanych ${ }^{46}$.

Pobożny kalwin, który wedle ojca-założyciela swojej doktryny powinien z całą determinacją potępiać myśl o samobójstwie, zdawał się może tylko ze wstydu i strachu - dążyć uparcie do tego celu. Odniesienia do wiary są jednak nieliczne. Przy łóżku w więziennej celi znaleziono, jak pisała prasa, bardzo popularny traktat anglikańskiego kaznodziei i polemisty Williama Sherlocka (1641-1707) A Practical Discourse upon Death (z 1689 r., ale wznawiany 27 razy w XVIII w.), dzieło jak najbardziej wskazane dla osoby, która udawała się na szubienicę. Zanim zastrzelił Matthewsa, morderca kręcił się w stanie depresji po okolicy, mówiąc, że „Bóg go opuścił”, natomiast - znów wedle doniesień prasy - na murze więziennego dziedzińca napisał czerwona ochrą (red oker): „O Lucyferze, synu poranka, jakże zszedłeś do piekieł tutaj do lochu"47. Nie ustalimy, czy to bełkot zagłodzonego i zmarnowanego więziennymi warunkami życia skazańca, czy tylko prasowa plotka.

Crawford, który odwiedził go w więzieniu, był zaskoczony stanem psychicznym i wynędzniałym wyglądem Niemca. Dla współczesnych nie było to jednak zaskoczeniem: Newgate uchodziło za siedlisko brudu i bardzo zatłoczoną (po trzydziestu więźniów w jednej sali) wylęgarnię chorób. W 1750 r. na „więzienna gorączkę” zmarło 60 osób, a pożar na dziedzińcu w 1762 r. zabił dwóch więźniów ${ }^{48}$. Skazańców można było odwiedzać i Stirn nie zerwał kontaktu ze swoimi ziomkami i współwyznawcami,

${ }^{46}$ R. McGowen, „He Beareth Not the Sword in Vain”. Religion and Criminal Law in Eighteenth-Century England, „Eighteenth-Century Studies” 21, 1987-1988, 2, s. 192-211.

47 "the minister of the German chapel [- - ] has frequently said to me, this unhappy man is indeed mad, and I would have you get him shaved and bleeded every month, if possible”, OBSP, ref. nr 17600910-19, s. 12. Napis na murze: „O Lucifer, son of the morning, how art thou brought down to hell, to the side of this pit”, „London Magazine" 27, 1760, s. 490. Por. „I have abandoned my God and he has forsaken me”, „Universal Magazine” 27, 1760, s. 154; „by his bedside he had Sherlock upon Death”, „London Magazine" 29, 1760, s. 490.

${ }^{48}$ Zob. esej Stephena Halesa o „gorączce więziennej” w „London Magazine” 24, 1755, s. 118-119. Więzienie Newgate (dawna średniowieczna brama miejska) uchodziło za siedlisko chorób i nędzy (więźniowie sami musieli ponosić koszty utrzymania, płacili za wyżywienie i musieli opłacać się strażnikom), zob. W.J. Sheehan, Finding Solace in Eighteenth-Century Newgate, w: Crime in England 1550-1800, red. J.S. Cockburn, London 1977, s. 229-245; H.D. Kalman, Newgate Prison, „Architectural History” 12, 1969, s. 50-61 (z planami więzienia z czasu pobytu Stirna). 
chociaż - jak zaznawał Crawford (zapewne sam kalwin) „pastor z niemieckiej kaplicy [--] często mi mówił, że ten nieszczęśnik jest szalony i trzeba, byś kazał go ogolić i jeśli możliwe puszczać mu krew co miesiąc". Wypowiedź ta nosiła raczej znamiona ludowej wiedzy na temat sposobów leczenia, niż porad należących do arsenału duchowej pociechy. Więzienny kapelan nie prawił mu sążnistych morałów znanych z praktyki kaznodziejów, chociaż starał się pogodzić go z losem i Bogiem. Jedyna dalsza wzmianka o udziale duchownych w całej sprawie dotyczyła pastora (gazety pisały też o dwóch krajanach Stirna), który pojawił się w więzieniu, ale wydaje się tylko po to, aby ułatwić mu popełnienie samobójstwa. W całym zbiorze relacji o sprawie Stirna perspektywy medyczna, „kryminalna” i psychologiczna górowały nad wymiarem religijnym ${ }^{49}$.

\section{Dżentelmen}

Podsumowując swoją relację, kapelan z Newgate konstatował, że „[Stirn] złożony był z wewnętrznych sprzeczności”, co można odczytać jako potwierdzenie postępującego procesu alienacji, jakiemu wśród londyńczyków podlegał niemiecki innowierca i migrant. Perspektywa urażonego honoru i narażonej na szwank reputacji - werbalnie dominująca - ukrywa jednak jeszcze jeden, „rynkowy” charakter relacji między głównymi protagonistami.

Mimo swego statusu - najemnego nauczyciela - i obaw o utratę pozycji Stirn nie wydaje się człowiekiem, któremu brakowało zasobów. Pistolety - zakup dość kosztowny - nabył za gotówkę. W czasie burzliwego pożegnania w domu chirurga stwierdził, że nie brak mu pieniędzy, dodając mgliście - choć była to zapewne przechwałka odnosząca się do przyszłych dochodów (lekarz potraktował to jednak jako groźbę!), że „rozmawiał z człowiekiem, który spisze jego i Matthewsa żywot”. Mimo tej brawury był jednak tylko zależnym od swoich pracodawców „pracownikiem umysłowym”, bez statusu i pozycji w (drobno) mieszczańskiej strukturze angielskiej stolicy. Analizując przypadki samobójstw w Genewie (w długim okresie 1549-1798), Jeffrey Watt (idąc śladem Emila Durkheima), zwracał uwagę na wzrost ich liczby po 1750 r. i bezpośredni związek ze zjawiskiem izolacji społecznej ${ }^{50}$. Londyńska rzeczywistość nie

${ }^{49} \mathrm{O}$ tradycji duchowej pociechy dla opętanych zob. R.A. Houston, Clergy and the Care of the Insane in Eighteenth-Century Britain, „Church History” 73, 2004, 1, s. 114-138.

50 „I have spoke with a man to day that will write my life and your's”, OBSP, ref. nr 17600910-19, s. 2. Zob. J. Watt, op. cit., s. 166-186, 263-264. 
sprostała oczekiwaniom Stirna, a repertuar jego społecznie osadzonych odruchów natrafił na niezrozumienie. Nawet publicznie wypowiedziany wulgaryzm wobec pani Matthews nie doprowadził ani do wyzwania, ani - jak dawniej - do konsystorskiego procesu o zniesławienie, ani nawet do rękoczynu, ponieważ - jak dowodził Robert Shoemaker mieszczański kanon grzeczności relegował takie zachowania poza nawias przyzwoitości. Publiczna obraza - podobnie jak agresja - wychodziły w XVIII w. z mody ${ }^{51}$.

Uważna lektura zeznań składanych w czasie procesu ujawnia wiele momentów, w których znajomi Stirna - świadomi paroksyzmów, w jakie popadał - usiłowali na przekór konfliktowym sytuacjom wyjaśniać jego zachowanie nie jako objawy obłędu, ale w kategoriach odstępstw od powszechnie przyjętych zasad towarzyskiej poprawności. 19 lipca na kilka dni przed wyprowadzeniem się od Crawforda - Stirn głośno perorował (rzucając tym razem inwektywy na Matthewsa). Gospodarz powiedział mu: ,proszę, nie mów głośno, to nie jest odpowiednie miejsce na takie tematy, idź do kawiarni". Nawet w oberży Pewter Platter, w napiętej już atmosferze, uczestnicy biesiady wypili (na jego prośbę) zdrowie Stirna, a jego coraz bardziej nieprzewidywalne zachowanie skomentował Crawford mówiąc: „na litość boską panie Stirn proszę, abyś umilkł, opanuj swoje namiętności („moderate your passion”)”. W przekonaniu świadków postępowanie i zachowanie Stirna, którego w akcie oskarżenia określono jako dżentelmena, kłóciło się z ich oceną i oczekiwaniami wobec tak sformułowanego - i dla nich zrozumiałego - pojęcia. We współczesnych badaniach nad społecznymi desygnatami pojęć, którymi posługiwali się osiemnastowieczni Anglicy, termin politeness, który chętnie tłumaczyłbym tutaj jako obyczajność, zajmuje miejsce kluczowe i wyznacza - jak tłumaczył Lawrence Klein - odkrycie nowych możliwości rozpoznania zachodzącej w XVIII w. kulturowej transformacji ${ }^{52}$. Podobnie jak jego znajomi - nauczyciel i lekarz - Stirn był dżentelmenem, a przynajmniej uznano go za takiego. A zatem za kogo? Jakie znacznie miało pojęcie, jakim go określono - i stojący za nim społeczny status? Próby odpowiedzi prowadzą w gąszcz nierozpoznanych do końca - frustrujących dla wielu historyków - poszukiwań,

51 „Thus he was in truth a composition of inconsistencies and self contradictions", Ordinary of Newgate Account, s. 158. Por. R.B. Shoemaker, The Decline, s. $115 \mathrm{nn}$.

52 L.E. Klein, Liberty, Manners and Politeness in Early Eighteenth-Century England, „The Historical Journal" 32, 1989, s. 583-605; idem, Politeness and the Interpretation of the British Eighteenth Century, „The Historical Journal” 45, 2002, s. 869-898; H. Berry, op. cit., s. $65-81$. 
w których nie tyle społecznie mierzalny status (majątek, pochodzenie, posiadanie nieruchomości), ile kulturowa i obyczajowa przynależność, własne poczucie bliskości i obecności w kręgu idei i przedmiotów wyznaczały przede wszystkim semantyczne, a potem dopiero socjologiczne odniesienia. Jak wskazywał Huv Bowen, aż 26,5 proc. właścicieli pakietu akcji Spółki Wschodnioindyjskiej - największej handlowej korporacji XVIII w. Anglii - określało się w 1774 r. jako „gentlemen”, chociaż w większości przypadków mamy do czynienia z drobnymi przedsiębiorcami, kupcami i rzemieślnikami, których społeczny status nie miał wiele wspólnego z „klasowym” rdzeniem (gentle) tego pojęcia. Od połowy XVIII w. termin ten rozpoczął swoją semantyczną migrację i był stosowany przez ludzi - takich jak Stirn, najemny pracownik umysłowy którym albo dzięki własnym zaletom, albo kontekstom środowiskowym udało się wpisać (lub zawłaszczyć) pożądaną przez wielu stanową przynależnośćs3.

Dlaczego podnoszenie głosu w mieszkaniu, w którym był gościem, ekstrawertyczne zachowania i agresja językowa (obraza innych) zdawały się nie przynależeć do zachowań obyczajnych, oczekiwanych przez jego znajomych? Jego ofiara - lekarz - dbał o „poprawne” (muzyczne) wykształcenie swojej żony i córki, nosił przy boku (dość już niemodną wśród szlachty) szpadę i starał się dołączyć do warstwy wykształconych, podejmując naukę autorów starożytnych, dążył zatem do osiągnięcia tych intelektualnych umiejętności, które w środowisku miejskich erudytów (i dyletantów) ceniono wysoko. W schemacie społecznych ról osiemnastowiecznej Anglii, zarysowanym jeszcze przez Edwarda Patricka Thompsona, zachowania Stirna - przeciwnie niż Matthewsa - nie mieściły się w rejestrze kultury „wysokiej” (tzn. nie-plebejskiej), spychały go na pogranicze „grzeczności”, poza poszukiwaną i aprobowaną normę poprawności, równowagi, wystudiowanego dystansu - tych cech, które wbudowały się, albo - używając terminu Rogera Chartiera - zostały „zawłaszczone” przez nowo powstającą kategorię „miejskiej” (a także już mieszczańskiej) normy kulturowej. W promowanym modelu „nowej obyczajności” wszelkie nadużycie gestu czy sposobu wyrażania się - jak

53 P.J. Cain, A.G. Hopkins, Gentlemanly Capitalism and British Expansion Overseas, 1: The Old Colonial System, 1688-1850, „The Economic History Review” 39, 1986, s. 501-525; P.J. Corfield, Class by Name and Number in Eighteenth-Century Britain, „History” 72, 1987, s. 38-61; H.V. Bowen, Investment and Empire in the Later Eighteenth Century. East India Stockholding, 1756-1791, „The Economic History Review” 42, 1989, 2, s. 194-95; D. Kuchta, The Making of the Self-made Man. Class, Clothing, and English Masculinity, 1688-1832, w: The Sex of Things. Gender and Consumption in Historical Perspective, red. V. de Grazia, E. Furlough, Berkeley Cal. 1996, s. 54-78. 
w przypadku zachowań Stirna - było patologią, generowaną przez moralne lub emocjonalne zaburzenia ${ }^{54}$.

Doktor Chapman, który uważał Stirna za przyjaciela, starał się traktować go wedle zwyczajów „grzecznego” środowiska - zapraszał go do domu na herbatę, towarzyski domowy rytuał obyczajnego zachowania w kręgu, w którym uczestniczyły także kobiety, a także spotykał się z nim w oberżach, gdzie dominowały męskie zachowania wspólnego, powszechnie wśród dżentelmenów aprobowanego picia (bardziej wina niż piwa). Ochłodzenie przyjaźni z pracodawcą wynikało z rzekomych starań Crawforda, aby ze swego lokatora „uczynić niewolnika” („to make a slave of him"). Bariera oddzielająca nawet najbardziej zaufaną służbę domową od jej mieszczańskich pracodawców była - pokazywała to Mary L. Bellhouse na przykładzie francuskiego malarstwa - bardzo realnym wyznacznikiem gradacji i społecznie zajmowanej pozycji. Stirn, który starał się być członkiem „świata pracodawców”, odebrał taką wiadomość jako głęboki afront ${ }^{55}$. Obyczajny londyński dżentelmen był wykształcony - Matthews studiował autorów klasycznych, jego żona i córka uczyły się muzyki - i bywały: doktor Chapman i Matthews chodzili do oberży, przestrzeni publicznej (podobnie jak kawiarnia) jak najbardziej wpisanej w miejski rytm prospołecznych zachowań. Przyszli tam z teatru przy ulicy Drury Lane, gdzie obaj świetnie bawili się na sztuce Samuela Foota (sztuka The Minor była satyrą na metodystów). Stirn - także przecież dżentelmen - nadużywał swoim zachowaniem zarówno praw rządzących sferą domową (wyrzucono go z dwóch mieszkań), jak publiczną (w jednej oberży pił na umór, w drugiej awanturował się i strzelał) ${ }^{56}$.

${ }^{54}$ E.P. Thompson, The Patricians and the Plebs, w: idem, Customs in Common, New York 1991, s. 16-96; R. Chartier, Popular Appropriations. The Readers and their Books, w: idem, Forms and Meanings. Texts, Performances and Audiences from Codex to Computer, Philadelphia 1995, s. 83-113; idem, From Texts to Manners, a Concept and its Books. „Civilté” between Aristocratic Distinction and Popular Appropriation, w: idem, The Cultural Use of Print in Early Modern France, Princeton 1987, s. 71-109; G.J. Barker-Benfield, The Culture of Sensibility. Sex and Society in Eighteenth-Century Britain, Chicago 1992.

55 „Universal Magazine” 27, 1760, s. 153. Por. M.L. Bellhouse, Crimes and Pardons. Bourgeois Justice, Gendered Virtue, and the Criminalized Other in Eighteenth-Century France, „Signs” 24, 1999, s. 959-1010, zwł. s. 963 nn.; L.E. Klein, Politeness, s. 893 z dalszą literaturą. Miejskie oberże i zwyczaje picia wśród mężczyzn (na przykładzie kolonialnej Ameryki, ale istotne także dla osiemnastowiecznej Anglii) analizowała Sharon V. Salinger, Taverns and Drinking in Early America, Baltimore Md. 2002.

${ }^{56}$ O przestrzeni domowej (i jej „, cywilizującej” wartości) zob. O. Hufton, Women and the Family Economy in Eighteenth-Century France, „French Historical Studies” 9, 1975, s. 1-22; N. Armstrong, The Rise of the Domestic Woman, w: The Ideology of Conduct. Essays in Literature and History of Sexuality, red. N. Armstrong, L. Tennenhouse, New York 1987, 
W takim kontekście, nie zapominając o jego jednostkowym psychologicznym ładunku, trzeba sytuować sprawę Stirna. Próbując opisywać domniemane cechy angielskiego „charakteru narodowego”, Paul Langford podkreślał szczególne iunctim między tym, co wiązano z zachowaniem „naturalnym”, wyzbytym ostentacji, a towarzyską ogładą, która objawiała się w respektowaniu manier ${ }^{57}$. W relacji kapelana więziennego czytamy, że „największym błędem jego umysłu były - jak dostrzegłem jego pycha, próżność i bałwochwalcza (idolising) cześć dla honoru. Aby je usunąć, zalecono mu szczerą modlitwę w nadziei, że oddali samą myśl o samobójstwie". Jak przypominała Donna Andrew, dla wielu osiemnastowiecznych komentatorów zjawiska samobójstwa - kapelan okazywał się wierny tej tradycji - podstawową jego przyczyną był grzech pychy oraz nieposkromione namiętności - cechy i stany, które kod mieszczańskiego zachowania odrzucał ${ }^{58}$. Stereotyp, który nadawał samobójstwu miary szlachetnej (i „modnej”, bo w stylu Katona) śmierci okazywał się zużyty, a motyw samobójstwa skrywał raczej poczucie alienacji i kryzys osobowości wywołany nagłymi zmianami, m.in. trudnościami finansowymi czy bankructwem. W rynkowo zorientowanym społeczeństwie samobójstwo popełniali raczej nieudacznicy, nie zaś naśladowcy rzymskiego stoika. Stirn obracał się wśród ludzi jeśli nie zamożnych (chirurg nie miał aż takich możliwości zarobkowych jak np. dyplomowany lekarz), to żyjących dostatnio (Matthews zatrudniał dwie służące), hołdujących środowiskowej poprawności i uznających swoją małą miejską stabilizację za wartość. Jego zachowanie nie było ani „naturalne”, ani „grzeczne”, czyli obyczajne. Zagubiony w wielkomiejskim świecie niemiecki nadwrażliwy i pobudliwy imigrant zbuntował się przeciw londyńskim normom towarzyskiej poprawności. I przegrał.

s. 96-141; S. West, The public nature of private life. The conversation piece and the fragmented family, „British Journal of Eighteenth-Century Studies” 18, 1995, s. 152-171, zwł. s. 156 nn.; L.E. Klein, Politeness, s. 879 nn. Por. też R.B. Shoemaker, Male Honour and the Decline of Public Violence in Eighteenth-Century London, „Social History” 26, 2001, s. 190-208.

57 P. Langford, Englishness Identified. Manners and Customs 1650-1850, Oxford 2003, S. 88.

58 „I perceived his strongest error of mind was his pride, vain glory and idolizing his honor to remove which earnest prayer was recommended to him in hopes to cure him of the very thought of suicide", Ordinary of Newgate Account, s. 155. Por. D. Andrew, Debate, s. 162; J. Barrell, op. cit., s. 227 nn. 


\section{Streszczenie}

15 sierpnia 1760 r. Francis Stirn, młody duchowny kalwiński z Kassel, zatrudniony przez londyńskiego chirurga Richarda Matthewsa w charakterze prywatnego nauczyciela, zastrzelił swojego chlebodawcę. Zabójstwo zostało popełnione publicznie, późnym wieczorem w gospodzie Pod Cynową Misą w Holborn. Zbrodnię, popełnioną rzekomo w obronie honoru, przeanalizowano na podstawie rejestrów sądowych, tzw. Old Bailey Proceedings, raportu kapelana więzienia w Newgate, a także doniesień prasowych poświęconych sprawie. Rozpatrywano ją w kontekście szaleństwa, zarówno z punktu widzenia medycyny, jak i prawa. Emocjonalne niezrównoważenie zabójcy badano na tle rozwijających się koncepcji miejskiej grzeczności i ogłady. Ostateczny koniec Stirna - podjęta samodzielnie decyzja o samobójstwie w celu uniknięcia publicznego powieszenia - wskazuje na nierozwiązany kryzys mentalny i społeczny, będący konsekwencją kulturowej alienacji w rynkowo zorientowanym wielkomiejskim środowisku.

\section{Stirn's Honour: Murder, Madness and Social Norms in Eighteenth-Century London}

On 15 August 1760 Francis Stirn, a young Calvinist minister from Cassel who worked as a private tutor, shot Richard Matthews, a London surgeon. The murder was committed publicly, late in the evening at the Pewter Platter Inn at Holborn. Old Bailey Proceedings, "Ordinary of Newgate Report", as well as press coverage of the case serve to research the interconnection of crime committed reputedly in defence of honour with the notions of medical and legal madness. The murderer's emotional imbalance is viewed against the evolving concepts of urban gentility and politeness, while his ultimate end - self-made choice of suicide instead of public hanging - suggests an unresolved mental and social crisis resulting from cultural maladjustment in urban market-oriented environment.

Translated by Paweł T. Dobrowolski

\section{Bibliografia}

Andrew Donna, Debate. The Secularization of Suicide in England 1660-1800, „Past \& Present" 119, 1988, s. 158-165.

Andrew Donna, The Code of Honour and its Critics. The Oposition to Dueling in England 1700-1850, „Social History” 5, 1980, s. 409-434.

Andrews Jonathan, Scull Andrew, Customers and the Patrons of the Mad-Trade. The management of Lunacy in Eighteenth-Century London, University of California Press, Berkeley, Cal. 2003.

Andrews Jonathan, Scull Andrew, Undertaker of the Mind. John Monro and mad-Doctoring in Eighteenth-Century England, University of California Press, Berkeley, Cal. 2001. 
Armstrong Nancy, The Rise of the Domestic Woman, w: The Ideology of Conduct. Essays in Literature and History of Sexuality, red. Nancy Armstrong, Leonard Tennenhouse, Methuen, New York 1987, s. 96-141.

Babb Lawrence, Sanity in Bedlam. A Study of Robert Burton's Anatomy of Melancholy, The Michigan State University press, East Lansing 1959.

Barker-Benfield G.J., The Culture of Sensibility. Sex and Society in Eighteenth-Century Britain, University of Chicago Press, London-Chicago 1992.

Barrell John, Coffee-House Politicians, ,Journal of British Studies” 43, 2004, 2, s. 206-232. Baxter Vern, Margavio A.V., Honor, Status, and Aggression in Economic Exchange, „Sociological Theory” 18, 2000, 3, s. 399-416.

Beattie John, Crime and the Courts in England 1660-1800, Princeton University Press, Princeton N.Y. 1986.

Beattie John, Policing and Punishment in London, 1660-1750. Urban Crime and the Limits of Terror, Oxford University Press, Oxford 2001.

Beattie John, Sir John Fielding and Public Justice. The Bow Street Magistrates' Court 17541780, „Law \& History Review” 25, 2007, 1, s. 61-100.

Bellhouse Mary L., Crimes and Pardons. Bourgeois Justice, Gendered Virtue, and the Criminalized Other in Eighteenth-Century France, „Signs” 24, 1999, s. 959-1010.

Berry Helen, Rethinking Politeness in Eighteenth Century England. Moll King's Coffee House and the Significance of „Flash Talk”, „Transactions of the Royal Historical Society" 6 ser., 11, 2001, s. 65-81.

Bowen Huv V., Investment and Empire in the Later Eighteenth Century. East India Stockholding, 1756-1791, „The Economic History Review” 42, 1989, 2, s. 186-206.

Byrd Max, Visits to Bedlam. Madness and Literature in the Eighteenth Century, University of South Carolina Press, Columbia South Car. 1974.

Cain P.J., Hopkins A.G., Gentlemanly Capitalism and British Expansion Overseas, 1: The Old Colonial System 1688-1850, „The Economic History Review” 39, 1986, s. 501-525.

Chartier Roland, From Texts to Manners, a Concept and its Books. „Civilté" between Aristocratic Distinction and Popular Appropriation, w: idem, The Cultural Use of Print in Early Modern France, Princeton University Press, Princeton 1987, s. 71-109.

Chartier Roland, Popular Appropriations. The Readers and their Books, w: idem, Forms and Meanings. Texts, Performances and Audiences from Codex to Computer, University of Pennsylvania Press, Philadelphia 1995, s. 83-113.

Cockburn James, Early Modern Assize Records as Historical Evidence, "Journal of the Society of Archivists" 5, 1975, s. 215-231.

Cole Michael, Adam Beyer, Pianoforte Maker, „The Galpin Society Journal” 48, 1995, s. $94-119$.

Corfield Penelope J., Class by Name and Number in Eighteenth-Century Britain, „History” 72, 1987, s. 38-61.

Dabhoiwala Faramerz, The Construction of Honour, Reputation and Status in Late Seventeenth- and Early Eighteenth-Century England, „Transactions of the Royal Historical Society" 6 ser., 6, 1996, s. 201-213.

Davis Lennard J., Wicked Actions and Feigned Words. Criminals, Criminality and the Early English Novel, „Yale French Studies” 59, 1980, s. 106-118.

DePorte Michael V., Nightmares and Hobbyhorses. Swift, Sterne and the Augustan Ideas of Madness, Huntingdon Library, San Marino Cal. 1974. 
Dingwall Helen, „To Be Insert in the Mercury”: Medical Practitioners and the Press in Eighteenth-Century Edinburgh, „Social History of Medicine” 13, 2000, 1, s. $23-44$.

Doughty Oswald, The English Malady of the Eighteenth Century, „The Review of English Studies" 2, 1926, s. 257-269.

Eigen Joel P., Witnessing Insanity. Madness and Mad-Doctors in the English Court, Yale University Press, New Haven, Conn. 1995.

Emsley Clive, Hard Men. Violence in England since 1750, Hambledon, London 2005.

Faller Lincoln B., Criminal Opportunities in the Eighteenth Century. The "Ready-Made" Contexts of the Popular Literature of Crime, "Comparative Literature Studies” 24, 1987, 2, s. 120-145.

Faller Lincoln B., Turned into Account. The Forms and Functions of Criminal Biography in Late Seventeenth - and Early Eighteenth-Century England, Cambridge University Press, Cambridge 1987.

Forbes Thomas R., Surgeons at the Bailey. English Forensic Medicine to 1878, Yale University Press, New Haven Conn. 1985.

Foyster Elizabeth, „Boys Will be Boys?” Manhood and Aggression 1660-1800, w: English Masculinities 1660-1800, red. Tim Hitchcock, Michele Cohen, Longman, Harlow 1999, s. 151-166.

From Sin to Insanity. Suicide in Early Modern Europe, red. Jeffrey R. Watt, Cornell University Press, Ithaca 2004.

Gelbart Nina R., The King's Midwife. A History and Mystery of Madame du Coudray, University of California Press, Berkeley Ca. 1998.

Habermas Jürgen, The Structural Transformation of the Public Sphere. An Inquiry into a Category of Bourgeois Society, MIT Press, Cambridge Mass. 1989.

Harris Michael, Trials and Criminal Biographies: A Case Study in Distribution, w: Sale and Distribution of Books from 1700, red. Robin Myers, Michael Harris, Polytechnic Press, Oxford 1982, s. 1-36.

Harvey Karen, The Century of Sex? Gender, Bodies, and Sexuality in the Long Eighteenth Century, "The Historical Journal” 45, 2002, 4, s. 899-916.

Healy Roisin, Suicide in Early Modern and Modern Europe, „The Historical Journal” 49, 2006, s. 903-919.

Hitchcock Tim, „Unlawfully Begotten on Her Body”. Illegitimacy and the Parish Poor in St. Luke's Chelsea, w: Chronicling Poverty. The Voices and Strategies of the English poor 1640-1840, red. Tim Hitchcock, Peter King, Pamela Sharpe, McMillan, London 1997, s. 70-87.

Hitchcock Tim, Down and Out in Eighteenth Century London, Hodder Arnold, LondonNew York 2007.

Hitchcock Tim, Shoemaker Robert, Tales from the Hanging Court, Hodder Arnold, London 2007.

Hoffer Peter C., N.E.H. Hull, „Murdering Mothers”. Infanticide in England and New England 1558-1803, New York University Press, New York 1981.

Honour and Shame. The Values of the Mediterranean Society, red. John G. Peristiany, University of Chicago Press, Chicago 1966.

Houston Robert A., Clergy and the care of the Insane in Eighteenth Century Britain, "Church History" 73, 2004, 1, s. 114-138. 
Houston R.A., Courts, Doctors and Insanity Defences in $18^{\text {th }}$ and $19^{\text {th }}$ Century Scotland, „International Journal of Law \& Psychiatry” 26, 2003, 4, s. 339-354.

Houston R.A., Madness and Society in Eighteenth-Century Scotland, Oxford University Press, Oxford 2000.

Hufton Olwen, Women and Family Economy in Eighteenth-Century France, „French Historical Studies" 9, 1975, s. 1-22.

Kalman Harold D., Newgate Prison, „Architectural History” 12, 1969, s. 50-61.

Kelly Jason M., Riots, Revelries, and Rumor. Libertinism and Masculine Association in Enlightenment London, "Journal of British Studies” 45, 2006, 4, s. 759-795.

Kent David A., „Gone for a Soldier”. Family Breakdown and the demography of Desertion in a London Parish, 1750-1791, „Local Population Studies” 45, 1990, s. 27-45.

King Peter, The Impact of Urbanization on Murder Rates and on the Geography of Homicide in England and Wales, 1780-1850, „The Historical Journal” 53, 2010, s. 671-698.

Klein Lawrence E., Coffeehouse Civility 1660-1714. An Aspect of Post-Courtly Culture in England, „Huntingdon Library Quarterly” 59, 1997, 1, s. 30-51.

Klein Lawrence E., Liberty, Manners and Politeness in Early Eighteenth Century England, „The Historical Journal” 32, 1989, s. 583-605.

Klein Lawrence E., Politeness and the Interpretation of the British Eighteenth Century, „The Historical Journal” 45, 2002, s. 869-898.

Kuchta David, The Making of the Self-Made Man. Class, Clothing and the English Masculinity 1688-1832, w: The Sex of Things. Gender and Consumption in Historical Perspective, red. Victoria de Grazia, Ellen Furlough, University of California Press, Berkeley Cal. 1996, s. 54-78.

Landsman Stephen, One Hundred Years of Rectitude: Medical Witnesses at the Old Bailey, 1717-1817, „Law \& History Review” 16, 1998, 3, s. 445-494.

Langbein John H., The Criminal Trial before the Lawyers, „University of Chicago Law Review" 45, 1978, 2, s. 263-316.

Langford Paul, British Politeness and the Progress of Western Manners. An Eighteenth-Century Enigma, „Transactions of the Royal Historical Society” 6 ser., 7, 1997, s. 53-72.

Langford Paul, Englishness Identified. Manners and Customs 1650-1850, Oxford University Press, Oxford 2003.

Laqueur Thomas, Bodies, Death and Pauper Funerals, „Representations” 1, 1983, s. $109-131$.

Linebaugh Peter, The London Hanged. Crime and Civil Society in the Eighteenth Century, Cambridge University Press, Cambridge 1992.

Linebaugh Peter, The Ordinary of Newgate and His Account, w: Crime in England 15501800, red. James S. Cockburn, Princeton University Press \& Methuen, Princeton-London 1977, s. 246-270.

Lüsebrink Hans-Jürgen, Kriminalität und Literatur im Frankreich des 18. Jahrhunderts, Oldenbourg, München 1983.

Lüsebrink Hans-Jürgen, L'Innocence persecutée et ses avocats. Rhetorique et impact public du discours „sensible” dans la France du XVIII ${ }^{e}$ siècle, „Revue d'histoire moderne et contemporaine" 40, 1993, 1, s. 86-101.

MacDonald Michael, Lunatics and the State in Georgian England, "Social History of Medicine" 2, 1989, 3, s. 299-313. 
MacDonald Michael, Murphy Terence R., Sleepless Souls. Suicide in Early Modern England, Clarendon Press, Oxford 1990.

MacDonald Michael, The Medicalization of Suicide in England. Laymen, Physicians, and Cultural Change 1500-1870, „The Milbank Quarterly” 67, 1989, s. 69-91.

Maunder Richard, The Earliest English Square Piano?, „The Galpin Society Journal” 42, 1989, s. 77-84.

McClure Ruth K., Coram's Children. The London Foundling Hospital in the Eighteenth Century, Yale University Press, New Haven-London 1981.

McGowen Randal, „He Beareth Not the Sword in Vain”. Religion and Criminal Law in Eighteenth-Century England, „Eighteenth-Century Studies” 21, 1987-1988, 2, s. 192-211.

McKenzie Andrea, "This Death Some Strong and Stout Hearted men Doth Choose”. The Practice of „Peine Forte et Dure” in Seventeenth- and Eighteenth-Century England, „Law \& History Review” 23, 2005, 2, s. 279-313.

McLynn Frank, Crime and Punishment in Eighteenth-Century England, Routledge, London 1989.

McMullan John L., The Canting Crew. London's Criminal Underworld, 1550-1700, Rutgers University Press, New Brunswick 1984.

Medical Fringe and Medical Orthodoxy 1750-1850, red. William F. Bynum, Roy Porter, croom Helm, London 1986.

Mediterranean Countrymen. Essays in the Social Anthropology of the Mediterranean, red. Julian Pitt-Rivers, Mouton, Paris 1964.

Men and Violence. Gender, Honor, and Rituals in Modern England and America, red. Pieter Spierenburg, Ohio State University Press, Columbus Oh. 1998.

Merrick Jeffrey, Patterns and Prosecution of Suicide in Eighteenth-Century Paris, „Historical Reflections" 16, 1989, s. 1-53.

Moran Richard, The Origin of Insanity as A Special Verdict: the Trial for Treason of James Hadfield (1800), „Law \& Society” 19, 1985, 3, s. 487-519.

Parry-Jones William Ll., The Trade in Lunacy. A Study of Private Madhouses in England and Wales in the Eighteenth and Nineteenth Centuries, Routledge \& Kegan Paul, London 1972.

Peltonen Markku, The Duel in Early Modern England. Civility, Politeness and Honour, Cambridge University Press, New York 2003.

Pincus Steven, "Coffee Politicians Does Create”. Coffeehouses and Restoration Political Culture, „Journal of Modern History” 67, 1996, s. 807-834.

Policing and Prosecution in Britain 1750-1850, red. Douglas Hay, Francis Snyder, Clarendon, Oxford 1989.

Rabin Dana, Drunkeness and Responsibility for Crime in the Eighteenth Century, „Journal of British Studies" 44, 2005, 3, s. 457-477.

Rawlings Philip, Drunks, Whores and Idle Apprentices. Criminal Biographies of the Eighteenth Century, Routledge, London 1992.

Rogers Nicolas, London's Marginal Histories, „Labour/Le Travail” 60, 2007, s. 217-234.

Salinger Sharon V., Taverns and Drinking in Early America, John Hopkins University Press, Baltimore Md. 2002.

Sharpe James A., Last Dying Speeches. Religion, Ideology and Public Execution in Seventeenth-Century England, „Past \& Present” 107, 1984, s. 144-167. 
Sheehan W.J., Finding Solace in Eighteenth-Century Newgate, w: Crime in England 15501800, red. James S. Cockburn, Methuen, London 1977, s. 229-245.

Sherbo Arthur, From the Westminster Magazine. Swift, Goldsmith, Garrick Et Al., „Studies in Bibliography" 41, 1988, s. 270-283.

Shoemaker Robert B., Male Honour and the Decline of Public Violence in Eighteenth-Century London, „Social History” 26, 2001, s. 190-208.

Shoemaker Robert B., The Decline of Public Insult in London 1660-1800, „Past \& Present” 169, 2000, s. 97-131.

Shoemaker Robert, Reforming Public Manners. Public Insult and the Decline of Violence in London 1660-1740, w: English Masculinities 1660-1800, red. Tim Hitchcock, Michele Cohen, Longman, Harlow 1999, s. 133-150.

Shoemaker Robert, The London Mob. Violence and Disorder in Eighteenth-century England, Hambledon, London-New York 2004.

Shoemaker Robert, The Taming of the Duel. Masculinity, Honour, and the Ritual Violence in London 1660-1800, „The Historical Journal” 45, 2002, s. 525-545.

Sienna Kevin P., Pollution, Promiscuity, and the Pox. English Venereology and the Early Modern Medical Discourse on Social and Sexual Danger, „Journal of the History of Sexuality" 8, 1998, 4, s. 553-574.

Simpson Anthony E., Popular Perceptions of Rape as a Capital Crime in Eighteenth-Century England. The Press and the Trial of Francis Charteris in the Old Bailey, February 1730, „Law \& History Review” 22, 2004, 1, s. 27-70.

Smail John, Credit, Risk, and Honour in Eighteenth-Century Commerce, „Journal of British Studies" 44, 2005, 3, s. 439-456.

Sorensen Janet, Vulgar Tongues. Canting Dictionaries and the Language of the People in Eighteenth-Century Britain, „Eighteenth-Century Studies” 37, 2004, 2, s. 435-454. Spierenburg Pieter, A History of Murder. Personal Violence in Europe from the Middle Ages to the Present, Polity, Cambridge 2005.

Stone Lawrence, Interpersonal Violence in English Society, 1300-1980, „Past \& Present” 101, 1983, s. 22-33.

Thompson Edward P., The Patricians and the Plebs, w: Edward P. Thompson, Customs in Common, New Press - Merlin Press, London-New York 1991, s. 16-96.

Watt Jeffrey R., Choosing Death. Suicide and Calvinism in Early Modern Geneva, Truman State University Press, Kirksville 2001.

West Shearer, The Public Nature of Private Life. The Conversation Piece and the Fragmented Family, „British Journal of Eighteenth-Century Studies” 18, 1995, s. 152-171.

Wilson Adrian, Illegitimacy and its Implications in Mid-Eighteenth Century London, „Continuity and Change" 4, 1989, 1, s. 103-164.

Biogram: Paweł T. Dobrowolski, prof. dr hab., zatrudniony w Collegium Civitas w Warszawie, gdzie kieruje Katedrą Studiów Społecznych, Politycznych i Międzynarodowych; były dyplomata RP w Kanadzie i na Cyprze; obszar zainteresowań: osiemnastowieczna Wielka Brytania; kontakt: pawdob@hotmail.com. 